\title{
Integration of Abscisic Acid Signaling with Other Signaling Pathways in Plant Stress Responses and Development
}

\author{
Manu Kumar ${ }^{1, *(\mathbb{D})}$, Mahipal Singh Kesawat ${ }^{2}{ }^{(\mathbb{D}}$, Asjad Ali $^{3}$, Sang-Choon Lee ${ }^{4}$, \\ Sarvajeet Singh Gill ${ }^{5}$ and Hyun Uk Kim ${ }^{1, *(\mathbb{B}}$ \\ 1 Department of Bioindustry and Bioresource Engineering, Plant Engineering Research Institute, \\ Sejong University, Seoul 05006, Korea \\ 2 Department of Agriculture, Sri Sri University, Cuttack 754-006, India; kesawatbsmahi@gmail.com \\ 3 Southern Cross Plant Science, Southern Cross University, East Lismore NSW 2480, Australia; \\ asjaddu@gmail.com \\ 4 Phyzen Co, Seongnam 13558, Korea; sclee0923@phyzen.com \\ 5 Stress Physiology and Molecular Biology Lab, Centre for Biotechnology, MD University, Rohtak 124001, \\ India; ssgill14@mdurohtak.ac.in \\ * Correspondence: manukumar@sejong.ac.kr (M.K.); hukim64@sejong.ac.kr (H.U.K.)
}

Received: 2 November 2019; Accepted: 10 December 2019; Published: 11 December 2019

\begin{abstract}
Plants are immobile and, to overcome harsh environmental conditions such as drought, salt, and cold, they have evolved complex signaling pathways. Abscisic acid (ABA), an isoprenoid phytohormone, is a critical signaling mediator that regulates diverse biological processes in various organisms. Significant progress has been made in the determination and characterization of key ABA-mediated molecular factors involved in different stress responses, including stomatal closure and developmental processes, such as seed germination and bud dormancy. Since ABA signaling is a complex signaling network that integrates with other signaling pathways, the dissection of its intricate regulatory network is necessary to understand the function of essential regulatory genes involved in ABA signaling. In the present review, we focus on two aspects of ABA signaling. First, we examine the perception of the stress signal (abiotic and biotic) and the response network of ABA signaling components that transduce the signal to the downstream pathway to respond to stress tolerance, regulation of stomata, and ABA signaling component ubiquitination. Second, ABA signaling in plant development processes, such as lateral root growth regulation, seed germination, and flowering time regulation is investigated. Examining such diverse signal integration dynamics could enhance our understanding of the underlying genetic, biochemical, and molecular mechanisms of ABA signaling networks in plants.
\end{abstract}

Keywords: abscisic acid; abiotic stress signaling; ubiquitination; seed germination; E3 ubiquitin ligase; stomatal regulation

\section{Introduction}

Abscisic acid (ABA) signaling (perception, signaling, and tolerance) in plants is a complex response for which there are considerable knowledge gaps at the molecular level. ABA is a plant phytohormone with a small lipophilic sesquiterpenoid (C15) structure [1]. It has a key role in stress adaptation in addition to being critical in numerous biological processes, such as bud dormancy and seed germination [2-6]. In the 1960s, pioneering studies on ABA (initially termed "abscisin" and "dormin") reported that it was accumulated in immature cotton balls that succumbed to ethylene-triggered abscission and over-wintering buds $[4,7,8]$. Later, it was demonstrated that under such conditions 
and developmental stages, plants were experiencing drought stress [5,9-17]. Therefore, ABA is a misnomer [18], even though it plays a role in leaf senescence and seed dormancy, potentially via osmotic effects [19-21]. It has been observed that drought-stressed vegetative tissues of numerous plants accumulate ABA (40-fold induction) within hours of osmotic stress and then it decreases after rehydration. In addition, $\mathrm{ABA}$ has been considered a long-distance stress signal between shoots and roots [22]. Therefore, the study of spatiotemporal expression of genes that control ABA metabolism's rate-limiting steps is essential for understanding how plants adapt to stress. Other than its role in adaptation to abiotic stress, ABA has been shown to be a key regulator of pathogen virulence [23-27], which could offer insights into the basis of the ABA-synthesizing ability of numerous bio- and necrotrophic microbes [24,28-30].

Gene products acting in the vicinity of the cell wall or at the interface of the plasma membrane/cytoskeleton/cell wall are considered the most likely elements to participate in initial stress perception. For instance, gated aquaporins (plasma membrane intrinsic proteins (PIPs)) and osmo-/ion channels at the cell wall-plasma membrane interface may be implicated in the upstream perception [31-33]. The receptor of ABA remained unknown until 2009. Before then, several ABA receptors had been reported [34-40]; however, further investigations did not substantiate any of them. In 2009, two independent studies reported the steroidogenic acute regulatory protein (StAR)-related lipid-transfer (START) domain of the significant Bet v1 (birch pollen allergen) superfamily of proteins as candidate ABA receptors [41-44]. All 14 members of the protein family are called regulatory components of ABA receptor, RCAR1-RCAR14, [41], or pyrabactin resistance 1 (PYR1) and PYR1-like 1-13 [42]. The discovery of PYR1-like components (PYLs) laid the foundation for the unraveling of the ABA signaling mechanism in detail. Such findings opened the door for advancements in the ABA signaling field and were appropriately recognized as scientific breakthroughs of the year $[45,46]$. Multiple structure studies have clarified the interactions at the molecular level comprising a signaling cascade consisting of the PYL ABA receptors, the core ABA signaling pathway, Snf1-related protein kinases 2 (SnRK2s), and type 2C protein phosphatases (PP2Cs). ABA binding induces PYL protein interaction with the active site of PP2C and inhibits phosphatase activity by blocking the PP2C catalytic site (SnRK2 substrate) [47-51]. Such findings shed light on the ABA signaling transduction pathway, which could facilitate the unraveling of abiotic stress tolerance as well as various developmental processes in plants.

Numerous reviews have explored the specific aspects of ABA responses in detail [42,52-60], including the relationship between ABA signaling and abiotic stress responses, calcium signaling, MAPK signaling, and ubiquitination. In addition, abiotic stress tolerance has been reviewed extensively, although with less emphasis on seed development and lateral root formation, and no reviews have focused on the overall ABA signaling network [42,52-60]. ABA signaling is a complex network that works in tandem with other signaling pathways. Therefore, it is important to present an overall network taking into account recent advancements to fill the gaps that have not been addressed to date. In this review, we integrated signaling pathways that align with the ABA signaling pathway, which displays a complex network, being active during both plant abiotic stress tolerance and plant development. We also added recent findings to the existing ABA signaling network in plants.

\section{Ubiquitination in ABA Signaling}

Protein post-translational modification by ubiquitination has been studied during various aspects of stress responses, plant development, and growth [61,62]. Since ABA is a major phytohormone and plays a vital role in plant growth and stress responses, the regulation of its signaling components must be subjected to ubiquitination. Reports have emerged regarding E3 ligase-mediated ubiquitination of ABA signaling components [60]. The E3 ubiquitin ligases discussed in this review are indicated using dark red square boxes in Figure 1B,E. ABA receptors (PYR/PYL/RCAR) in plants are regulated by degradation via the ubiquitin-26S proteasome system. Damaged DNA binding protein 1 associated 1 (DDA1) from Cul4-based E3 ligase complexes and a single subunit, the RING-type E3 ligase RING 
FINGER OF SEED LONGEVITY1 (RSL1), are involved in the process [63,64], which suggests that, in the ABA signaling pathway, RSL1 acts as the negative regulator by regulating the ABA receptor through ubiquitination. Two plant U-box protein family members, PUB12 and PUB13, interact with ABI1. $A B I 1$ is induced in pub12/pub13 mutants compared within wild types irrespective of ABA presence; however, it can ubiquitinate ABI1 only in the presence of both PYR1 and ABA, which indicates that the interaction between PYR1 and ABI promotes ABI1 degradation by PUB12/13 [65]. An E3 ubiquitin ligase, PLANT U-BOX PROTEIN10 (PUB10), modulates ABA signaling in Arabidopsis. PUB10-OX plants phenocopied myc2, whereas the pub10 plants phenocopied MYC2-OX plants in response to ABA, indicating the regulation of MYC2 (a jasmonic acid (JA) signaling component) by PUB10 (Figure 2) [66]. A KEEP ON GOING (KEG) E3 ligase with a truncated RING domain also acts as a bait for the CIPK26 interaction because it acts as the negative regulator in ABA signaling $[67,68]$. ABA also induces the degradation of KEG by self-ubiquitination, resulting in the accumulation of ABI5 [69]. KEG also ubiquitinates and degrades $\mathrm{ABF} 1$ and $\mathrm{ABF} 3$ by interacting directly with them [70]. The results of the studies above suggested that ABF1, ABF3, and ABI5 were the substrates for E3 ligase KEG.

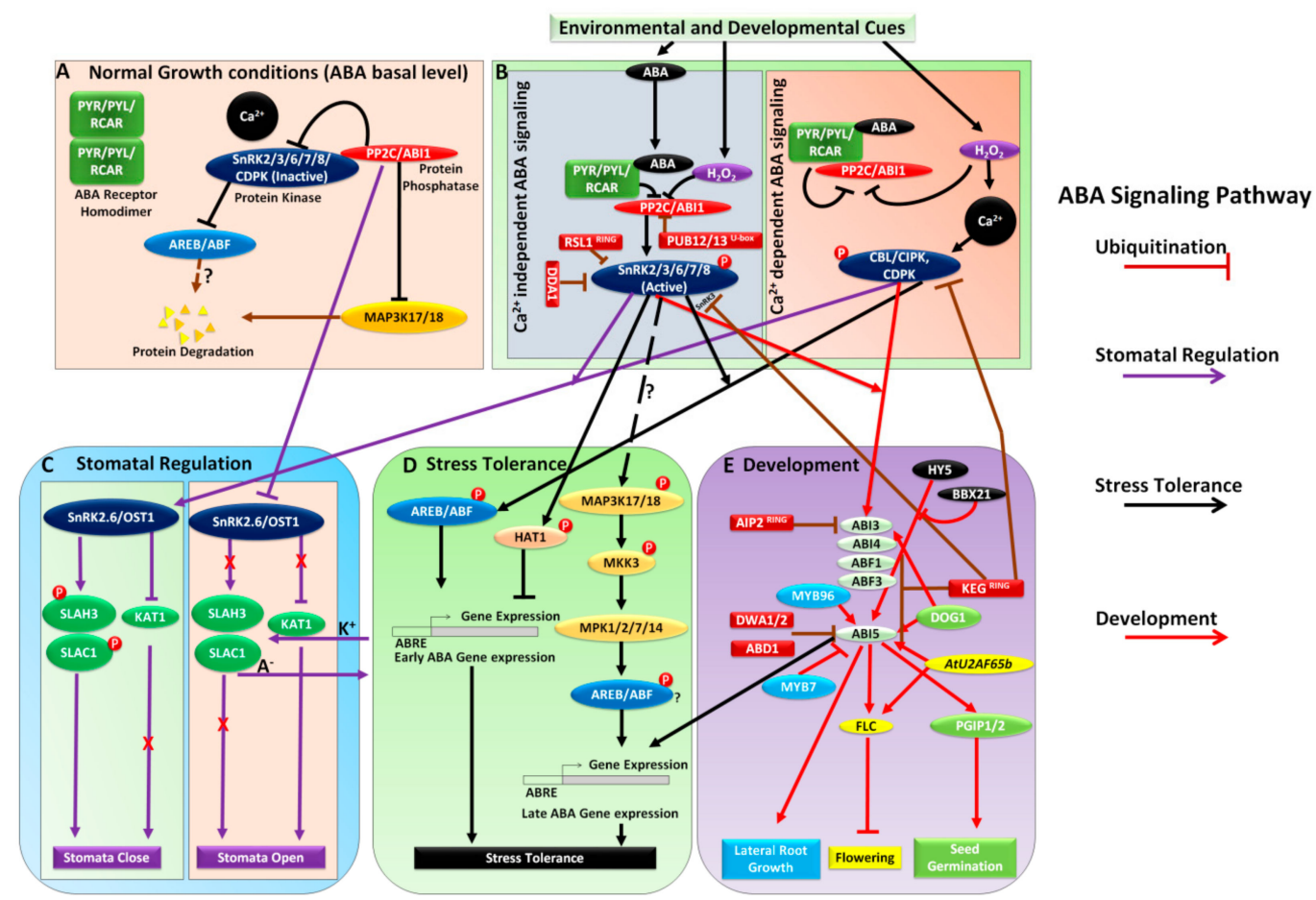

Figure 1. Overview of the abscisic acid (ABA) signaling pathway. (A) Inactivation of SnRKs, CIPKs, and CDPKs under normal growth conditions (light orange box). PP2C (red oval box) plays an important role in the inactivation of SnRKs, CIPKs, and CDPKs. Inactive MAP3K17/18 (orange oval box) and AREB/ABF (Abscisic Acid Response Element/Abre-Binding Factor) (yellow oval box) undergo protein degradation. (B) Initial perception of environmental and developmental cues. ABA signaling is transduced in $\mathrm{Ca}^{2+}$-independent (light blue box) as well as $\mathrm{Ca}^{2+}$-dependent (light orange box) manners. Active SnRKs, CIPKs, and CDPKs (dark blue oval box) play important roles in downstream signal transduction. (C) Stomatal regulation via ABA signaling in response to stress and healthy conditions. Under stress conditions, stomatal regulation (purple arrow $\rightarrow$ ) is carried out by active SnRK2.6/OST1 (blue oval box) through the regulation of downstream ion channel genes (green oval boxes), such as SLAH3, SLAC1, and KAT1. This regulation helps stomata remain closed to avoid loss of excessive water under adverse conditions. Under normal conditions, SnRK2.6/OST1 inactivated by PP2C cannot regulate the downstream genes; thus, stomata remain open. (D) Response to stress tolerance via the ABA signaling pathway. The stress tolerance mechanism (black arrow $\rightarrow$ ) is regulated in $\mathrm{Ca}^{2+}$-independent as well as $\mathrm{Ca}^{2+}$-dependent manners. The MAP kinase cascade (orange oval box) pathway carries the 
signal for the response to abiotic stress tolerance. It delays ABA gene expression. Contrarily, signal transduction via only AREB/ABF (yellow oval box) shows early expression of ABA related genes, resulting in an early response to stress tolerance. (E) Involvement of ABA signaling in the plant developmental process. Downstream ABA signaling involved in different developmental processes (red arrow $\rightarrow$ ) such as seed germination (light green oval and square boxes), lateral root growth (light blue oval and square boxes), and regulation of flowering time (yellow oval and square boxes). ABI5 emerges as a critical ABA signaling component in the regulation of the plant developmental process. ABA signaling integrates with light signaling (black dark oval box) to regulate plant development. The brown tack facing up $(\perp)$ indicates the role of ubiquitination in ABA signaling. These E3 ubiquitin ligase elements in ABA signaling guide the inactive protein to undergo degradation. The question mark (?) indicates the unknown pathway.

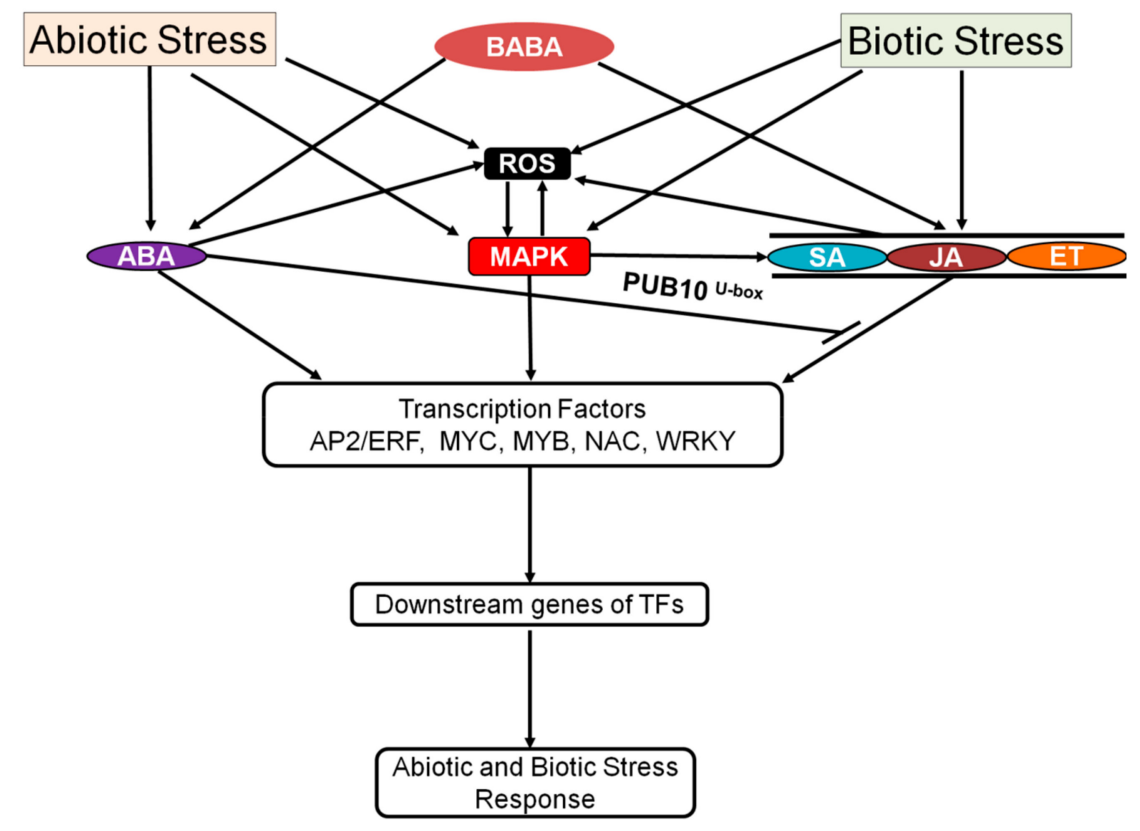

Figure 2. A simplified schematic diagram showing synergistic and antagonistic interactions between the ABA signaling pathway and other hormonal signaling pathways during abiotic and biotic stress.

ABD1, DWA1, and DWA2, which are associated with Cul4-based E3 ubiquitin ligases, were reported to be responsible for ABA signaling through the degradation of ABI5 by regulated ubiquitination in the nucleus via the ubiquitin-26S proteasome system [71-73]. Single mutants, $a b d 1$, dwa1, and $d w a 2$, and a double mutant, dwa1/dwa2, display ABA-hypersensitive phenotypes during seed germination and seedling growth [72,73], which indicates ABI5 acts as a target for ABD1, DWA1, and DWA2, Cul4-based E3 ubiquitin ligases, which leads to the negative regulation of ABA signaling in the nucleus. ABI3 INTERACTING PROTEIN2 is a functional RING-type E3 ligase that interacts with an unstable protein, ABI3, and is degraded via the ubiquitin-26S proteasome system [74]. Different types of E3 ligases with dual roles have been reported participating in the regulation of ABA signaling; however, the knowledge about their substrates and studies related to their association with ABA signaling is an ongoing process.

\section{ABA Signaling under Stress}

\subsection{Calcium Signaling Integration with ABA Signaling Pathway and Stomatal Regulation}

In plants, abiotic stress positively triggers the levels of ABA and reactive oxygen species (ROS) [75] such as $\mathrm{H}_{2} \mathrm{O}_{2}$ [76-79]. High $\mathrm{H}_{2} \mathrm{O}_{2}$ levels trigger cytosolic calcium concentration via nitric oxide (NO) $[80,81]$. Downstream signaling cascades regulate transcriptional responses to abiotic stress 
tolerance and stomatal regulation (Figure 1B-D) [53]. Many reports point to direct interactions between $\mathrm{ABA}$ and calcium signaling systems at different levels (Table 1). For such interactions between $\mathrm{ABA}$ and calcium signaling, $\mathrm{ABI} 1$ (clade A protein phosphatases $2 \mathrm{Cs}$ ) appear to function as master regulators [53,58,82]. In normal growth conditions (basal ABA level), $\mathrm{Ca}^{2+}$ and SnRK2/3/6/7/8/CDPK activity are inhibited by ABI1/PP2C. This inhibition prevents downstream signaling [83,84] (Figure 1A). In the presence of ABA (during stress or developmental stages), ABI1/PP2C activity is inhibited by ABA, which induces RCARs and elevated levels of $\mathrm{H}_{2} \mathrm{O}_{2}$, and in turn the conversion of ABA signals into appropriate cellular responses where SnRKs (2/3/6/7/8)/CDPK phosphorylate the downstream targets [53]. This is the classical ABA signaling pathway; however, recent findings have suggested that it is not that simple. It is potentially integrated with multiple signaling pathways, such as the calcium pathway. $\mathrm{Ca}^{2+}$, along with $\mathrm{ABA}$, represents a most versatile secondary messenger in eukaryotes and is involved in crucial aspects of signaling [85-88]. Stress signals that trigger cellular $\mathrm{ABA}$ levels can also invoke prominent cellular $\mathrm{Ca}^{2+}$ signals in plants, which are perceived downstream by calcineurin B-like proteins (CBLs)/CBL-interacting protein kinases (CIPKs) [89,90] (Figure 1B). The calcium sensor CBL-CIPK regulates a variety of downstream targets, such as regulation of stomata and ion channels [91-93]. $\mathrm{Ca}^{2+}$ - dependent protein kinases (CDPKs) have functions similar to those of CBL/CIPKs in ABA signaling [84,94-97]. OPEN STOMATA 1 (OST1), an SnRK2 protein, has been reported as functioning as a critical regulator in the ABA signaling module [98]. The ost1 mutant displays a stomatal closure defect under drought stress. Positional cloning of OST1 revealed its similarity to SnRK2.6 [99]. The ost1/snrk2.6 double mutant affects stomatal closure under both stress-driven ABA signaling and normal growth conditions. The ABA signaling pathway is regulated by the direct interaction of SnRK2.6/OST1 and PP2CA/ABI1 (Figure 1C) [100].

Table 1. List of the target genes that are regulated by ABA as well as $\mathrm{Ca}^{2+}$ signaling.

\begin{tabular}{|c|c|c|c|c|c|}
\hline Gene Name & $\begin{array}{l}\text { Accession } \\
\text { Number }\end{array}$ & Main Function & $\begin{array}{c}\text { Regulated by } \\
\mathrm{Ca}^{2+} \text {-Dependent ABA } \\
\text { Signaling }\end{array}$ & $\begin{array}{c}\text { Regulated by } \\
\mathrm{Ca}^{2+} \text {-Independent } \\
\text { ABA Signaling }\end{array}$ & Reference \\
\hline$A B I 5$ & AT2G36270 & bZIP TF & $\begin{array}{l}\text { CIPK11/26, activates by } \\
\text { phosphorylation }\end{array}$ & $\begin{array}{c}\text { SnRK2s' } \\
\text { phosphorylation } \\
\text { activation; PP2Cs' } \\
\text { dephosphorylated } \\
\text { inactivation }\end{array}$ & {$[67,101,102]$} \\
\hline$A B F 1 / 4$ & $\begin{array}{l}\text { AT1G49720/ } \\
\text { AT3G19290 }\end{array}$ & bZIP TF & $\begin{array}{l}\text { CPK4/11, activates by } \\
\text { phosphorylation }\end{array}$ & $\begin{array}{c}\text { SnRK2s' } \\
\text { phosphorylation } \\
\text { activation; PP2Cs' } \\
\text { dephosphorylated } \\
\text { inactivation }\end{array}$ & {$[101,103]$} \\
\hline AKT1 & AT2G26650 & $\begin{array}{l}\text { Potassium ion } \\
\text { channel }\end{array}$ & $\begin{array}{l}\text { CBL1/9/CIPK23, activates by } \\
\text { phosphorylation }\end{array}$ & $\begin{array}{l}\mathrm{HAI} 2 \text { and PP2CA, } \\
\text { regulate AKT1 }\end{array}$ & [104-106] \\
\hline AKT2 & AT4G22200 & $\begin{array}{l}\text { Potassium ion } \\
\text { channel }\end{array}$ & $\begin{array}{l}\text { CBL4/CIPK6, localized in } \\
\text { the plasma membrane }\end{array}$ & $\begin{array}{l}\text { PP2CA, regulates } \\
\text { AKT2 }\end{array}$ & {$[107,108]$} \\
\hline KAT1 & AT5G46240 & Potassium channel & $\begin{array}{l}\text { Inhibited by the SnRK2s and } \\
\text { involved in the stomatal } \\
\text { closure }\end{array}$ & $\begin{array}{l}\text { Inhibition by SnRK2s } \\
\text { is inhibited by ABI1, } \\
\text { involved in the } \\
\text { stomatal opening }\end{array}$ & {$[109,110]$} \\
\hline NPF6.3 & AT1G12110 & Nitrate transporter & $\begin{array}{l}\text { CBL1/9CIPK23, deactivates } \\
\text { under high nitrate } \\
\text { conditions and increases the } \\
\text { nitrate sensitivity }\end{array}$ & $\begin{array}{l}\text { ABI2 involved in the } \\
\text { dephosphorylation or } \\
\text { deactivation of } \\
\text { CBL1/CIPK23 }\end{array}$ & {$[111,112]$} \\
\hline SLAC1 & AT1G12480 & $\begin{array}{l}\text { Plasma membrane } \\
\text { anion channel }\end{array}$ & $\begin{array}{l}\text { Induced by the SnRK2s and } \\
\text { involved in stomatal closure }\end{array}$ & $\begin{array}{l}\text { Induction by SnRK2s is } \\
\text { inhibited byABI1, } \\
\text { involved in the } \\
\text { stomatal opening }\end{array}$ & {$[113,114]$} \\
\hline $\mathrm{RBOHF}$ & AT1G64060 & $\begin{array}{l}\text { Plasma membrane } \\
\text { superoxide } \\
\text { generation }\end{array}$ & $\begin{array}{l}\text { CBL1/9/IPK26, activates by } \\
\text { phosphorylation }\end{array}$ & $\begin{array}{l}\text { OST1 involved in } \\
\text { phosphorylation }\end{array}$ & {$[115,116]$} \\
\hline
\end{tabular}


Table 1. Cont.

\begin{tabular}{|c|c|c|c|c|c|}
\hline Gene Name & $\begin{array}{l}\text { Accession } \\
\text { Number }\end{array}$ & Main Function & $\begin{array}{c}\text { Regulated by } \\
\mathrm{Ca}^{2+} \text {-Dependent ABA } \\
\text { Signaling }\end{array}$ & $\begin{array}{c}\text { Regulated by } \\
\mathrm{Ca}^{2+} \text {-Independent } \\
\text { ABA Signaling }\end{array}$ & Reference \\
\hline RBOHD & AT5G47910 & $\begin{array}{l}\text { Plasma membrane } \\
\text { superoxide } \\
\text { generation }\end{array}$ & $\begin{array}{l}\text { CPK5, activates by } \\
\text { phosphorylation }\end{array}$ & - & [96] \\
\hline SnRK2.6/OST1 & AT4G33950 & $\begin{array}{l}\text { Calcium-independent } \\
\text { ABA-activated } \\
\text { protein kinase }\end{array}$ & $\begin{array}{l}\text { CBL/CIPL/CDPK, activates } \\
\text { by phosphorylation }\end{array}$ & $\begin{array}{l}\text { SnRK2.6 involved in } \\
\text { phosphorylation }\end{array}$ & {$[112,117]$} \\
\hline SLAH3 & AT5G24030 & Anion channel & $\begin{array}{c}\text { CBL1/9/CIPK23 } \\
\text { CPK21 involved in } \\
\text { phosphorylated activation; } \\
\text { CPK21 also recruits SLAH3 } \\
\text { onto the membrane }\end{array}$ & $\begin{array}{l}\text { ABI1 involved in } \\
\text { deactivation }\end{array}$ & {$[95,118,119]$} \\
\hline
\end{tabular}

The target proteins of $\mathrm{Ca}^{2+}$-dependent and -independent $\mathrm{ABA}$ signaling systems are also the target of other signaling systems. Reactive burst oxidases (RBOHs) are phosphorylated by SnRK2.6/OST1, CPK5, and CBL1-CIPK26 [96,115,116]. At normal ABA levels, SnRK2.6 is inactive, and PP2CA (ABI1) inhibits the S-type anion channel (SLAC1) and the activity of its homologs (SLAH3) [120]. In addition, SnRK2.6 cannot inhibit $\mathrm{K}^{+}$channel (KAT1) activity, which results in increased turgor pressure and stomatal opening [121]. To cope with stress, plants tend to close stomata to prevent water loss. ABA signaling would lead to the closure of stomata. Elevated ABA levels under stress conditions inhibit PP2CA activity and the phosphorylation of SnRKs $\left(\mathrm{Ca}^{2+}\right.$-dependent manner), CBL, CIPK, and CDPK $\left(\mathrm{Ca}^{2+}\right.$-independent manner) occurs leading to the phosphorylation of SLAC1/SLAH3 by CBL1/9-CIPK23, CPK3/6/21/23, and SnRK2.6/OST1 [84,95,118,122-125]. SnRK2.6/OST1 also inhibits K ${ }^{+}$ channel (KAT1) activity [126] and mediates the efflux of anions and influx of $\mathrm{K}^{+}$and decrease in turgor pressure that results in stomatal closure (Figure 1C).

\subsection{Abiotic Stress Signaling Integration with the ABA Signaling Pathway}

In plants, ABA signaling is an important tool for robust stress responses to environmental stimuli and developmental processes. Plants encounter numerous abiotic stress factors, such as water scarcity (drought or dehydration), low temperature (cold stress), and salinity (salt stress) [59,127]. The plant utilizes ABA to assess the stress impact and may continuously alter ABA signaling stages based on environmental and physiological conditions to delay processes, such as germination, development, and lateral root formation, as appropriate [128]. Under stress conditions, numerous genes are upregulated in plants via the ABA pathway. Promoter analysis of the ABA-inducible genes has indicated that they must have multiple cis-elements, such as ABREs (PyACGTGG/TC) $[129,130]$. Plant gene expression analyses have revealed conserved ABREs cis-acting elements in dehydration-inducible promoters [131]. Sequences of ABREs are also present in the genes that are expressed in the seeds (Figure 1D) [132].

The bZIP subfamily members (AREB1/ABF2, AREB2/ABF4, and ABF3) are induced by ABA, dehydration, and high salinity [133], and the overexpression of the above factors in transgenic plants has led to drought tolerance [133-135]. To establish the role of such AREB/ABF TFs in stress-responses in vegetative tissues, Yoshida et al. [136] generated an areb1/areb2/abf3 triple mutant. Microarray analysis revealed impaired stress-responsive gene expression. It also revealed many stress-responsive genes, such as LEA proteins, group A PP2Cs, and various types of TFs that lie downstream of AREB/ABF TFs. Most of such gene promoters contain ABRE sequences. The areb1/areb2/abf3 triple mutant was sensitive to drought-stress and was more resistant to ABA (primary root growth) when compared with other single and double mutants, suggesting that ABF3, AREB1, and AREB2 are the master TFs that regulate the ABRE-dependent gene expression under stress conditions in ABA signaling. HD-ZIP transcription factor (TF), HAT1, a critical regulator in brassinosteroid (BR) signaling, interacts with SnRK2s [137,138]. HAT1 suppresses ABA signaling and is involved in ABA regulation of drought response [138], which 
also suggests the integration of $\mathrm{BR}$ signaling with $\mathrm{ABA}$ signaling to regulate the downstream targets of abiotic stress tolerance.

Mitogen-activated protein kinases (MAPKs) are also involved in ABA signaling in response to abiotic stress $[57,139]$. Studies on MAPK inhibitors highlighted the link between ABA and MAPK signaling. For example, in barley, phenyl arsine oxide inhibited ABA-induced MAPK activation [140]. Apart from MPK3, MPK4, and MPK6, the only other MAPKs activated in response to ABA are MPK12 [141-143] and the C-clade MAPKs MPK1/2/7/14 [144-146]. In Arabidopsis, MAP3K17 and MAP3K18 function upstream of the MAP3Ks to activate MKK3 and MAP2K, and, therefore, the C-clade MAPKs (MPK1, MPK2, MPK7, and MPK14) in response to ABA signaling (Figure 1D) $[82,146,147]$. BiFC and yeast 2-hybrid techniques have been used to demonstrate the interactions between kinases in Nicotiana benthamiana [146,147]. In the mkk3 and map3k17/18 backgrounds, ABA-driven activation of MPK7 was significantly reduced [146]. Genetic analysis revealed that in ABA signaling, PYR/PYL/RCAR-SnRK2-PP2C (an ABA core signaling module) activates the MAP3K17/18-MKK3-MPK1/2/7/14 cascade through the transcriptional regulation of MAP3K17/18 followed by MAP3K activation [146,148]. MAP3K18 is also regulated directly by the PYR/PYL/RCAR-SnRK2-PP2C module, suggesting that PP2C phosphatase ABI1 interacts directly with MAP3K18 [82] (Figure 1D). MAP3K18 also controls RD29B and RAB18 expression, two known ABA and abiotic stress-responsive genes, indicating the role of ABRE genes downstream of the MAPK cascade for the ABA signaling-driven abiotic stress response in plants.

\subsection{Biotic Stress Signaling Integration with the ABA Signaling Pathway}

Plants respond to biotic and abiotic stress via crosstalk signals such as ABA, salicylic acid (SA)/jasmonic acid (JA)/ethylene (ET)-mediated defense signaling [149]. The role of ABA in the crosstalk between biotic and abiotic stress is very broad and is discussed in detail by recently published reviews [150,151]. A restraint function of ABA on the systemic acquired resistance pathway of SA induction has also been reported in tobacco [152]. Elicitors/effectors secreted by Pseudomonas syringae pv. tomato activate ABA biosynthesis along with ABA signaling, which leads to the inhibition of biotic defense responses [23]. However, several reports have shown the positive effect of ABA signaling on biotic and abiotic stress. For example, treatment with ABA and SA resulted in a short-term increase in $\mathrm{H}_{2} \mathrm{O}_{2}$ production, which induced tolerance to salinity, heat, and oxidative stress [153]. During infection in plants, stomata can act as passive passage for bacteria. P. syringae pv. tomato pathogen-associated molecular patterns (PAMPs) induce stomatal closure via ABA signaling, NO production, and flagellin receptor (FLS2), indicating the integration of biotic and abiotic signaling with ABA signaling in the regulation of stomata [154]. $\beta$-aminobutyric acid (BABA), a non-protein amino acid, has been reported as a link between heat tolerance, biotic stress, and ABA signaling. Plants treated with BABA become resistant to abiotic as well as biotic stress [155-158]. The ibs3, a BABA-induced sterility mutant, exhibits defected regulation of $A B A 1$, salt resistance, and BABA-induced pathogen [159]. A recent study described BABA as a natural molecule synthesized by plants under stress [160]. Therefore, it may be a new entry into the list of plant hormones. Isolation of an activation-tagged mutant of activated disease resistance 1 ( $a d r 1$ ) further consolidates the link between ABA-mediated biotic and abiotic signaling. The adr1 mutant displayed drought tolerance as well as disease resistance. Surprisingly, adr1 plants display sensitive phenotype toward salt and heat stress, suggesting antagonism between biotic stress and abiotic stress [161]. Recently, a study reported that PUB10 acts as a negative regulator of ABA signaling, which could also be intermediatory in JA signaling (Figure 2) [66]. MAPKs are also reportedly involved in plant defense response by regulating the JA- and SA signaling as well as downstreaming transcription factors. This is discussed in detail by a recently published review [162].

In Arabidopsis, the biotic stress-inducible AP2/ERF TF family proteins are associated with different abiotic stresses, such as cold, drought, salinity, heat, and light stress [70,163-165]. Many ROS-inducible genes are also induced by AtERF6 for protection against both biotic and abiotic stress [166]. Most of the ethylene response factors (ERFs) that display abiotic stress tolerance are induced not only by 
ethylene but also by other biotic stress associated phytohormones, such as JA and SA. Therefore, there is potential crosstalk between abiotic and biotic stress and responses via the ABA signaling pathway [167-170] (Figure 2).

\section{ABA Signaling in Plant Development}

\subsection{Role of ABA Signaling in Seed Germination and Lateral Root Formation}

ABA accumulates during seed development and seed germination. In mature seeds, ABA promotes the synthesis of LEA (Late embryogenesis abundant) proteins for desiccation tolerance. ABA also inhibits germination and stimulates dormancy in mature seeds [55]. ABI3 and $A B I 4$ control seed sensitivity and embryonic gene expression in plants [171]. abi3 mutant seeds display reduced dormancy and vivipary, caused by the strongest alleles. To control seed maturation, ABI3/VP1 binds directly to the promoters of Sph/RY. FUSCA3 (FUS3) and LEAFY COTYLEDON 2 (LEC2) genes encode TFs that are structurally related to VP1/ABI3 [172,173], and the genes interact with ABI5 [174], although VP1/ABI3 is involved directly in ABA signaling. A bZIP protein, ABA-INSENSITIVE5 (AB15), was identified via ABA insensitive germination screening [171]. In addition to ABI5, three AREB/ABF-type bZIP proteins, namely EEL, AREB3, and AtbZIP67/AtDPBF2, are expressed in the nuclei of developing seeds and play vital roles in seed germination $[175,176]$. During early germination and seed maturation under stress conditions, ABI5 regulates the direct expression of AtEm1 and AtEm6 (LEA class genes) $[130,175,177]$. A seed expressed gene, DELAY OF GERMINATION 1 (DOG1), is critical for dormancy induction. During Arabidopsis seed development, DOG1 interacts with $A B I 3$ and influences $A B I 5$ expression [178] (Figure 1E). PGIP1 and PGIP2 are associated with the process of seed germination, and they are direct targets of ABI5 [179,180]. Overall, all the above studies highlight the key role of ABI5 as a master regulator of seed development through the ABA signaling pathway. A negative regulator of lateral root formation, MYB96, activates the expression of $A B I 5$ and is involved in plant responses to salt and drought stress [181]. MYB7 also negatively regulates ABI5 expression in seeds [182] (Figure 1E). The above studies support the functional role of ABI5 in the ABA signaling pathway-dependent inhibition of lateral root growth under stress conditions [183].

\subsection{ABA and Light Signaling Convergence}

ABA and light are the endogenous hormonal and the external environmental cues that play vital roles in the regulation of seed germination and seed development. The ability of plants to integrate external signals with internal regulatory pathways is crucial for their survival $[184,185]$. However, the crosstalk between ABA signaling and light signaling and its underlying molecular mechanisms remain largely unclear. The involvement of TF HY5 in promoting seedling photomorphogenesis, root development, and early seedling growth has been studied extensively. It mediates ABA signaling responses in seed germination by binding directly to the $A B I 5$ promoter and regulating its expression [186]. Two major TFs in the phytochrome A pathway, FAR-RED IMPAIRED RESPONSE1 (FAR1) and FAR-RED ELONGATED HYPOCOTYL3 (FHY3), positively regulate ABA signaling by inducing ABI5 expression directly [187]. PIL5 (also known as PIF1), a phytochrome-interacting bHLH TF, also targets $A B I 5$ [188]. Conversely, BBX21, a transcriptional regulator that is involved in the regulation of seedling photomorphogenesis, negatively regulates $A B I 5$ expression by intervening in the binding of HY5 to the $A B I 5$ promoter [189]. In addition, ABI5 can regulate its own expression while BBX21 inhibits ABI5 activation (Figure 1E). BBX21 represses ABI5 activity by regulating the binding activities of both ABI5 and HY5 to the $A B I 5$ promoter [189]. The findings suggest that, in the light signaling pathway, multiple TFs regulate $A B I 5$ expression in the ABA signaling responses.

\subsection{ABA Signaling and Control of Flowering Time}

A variety of ABA signaling activities are involved in controlling meristem function or flowering time $[171,190]$. In addition, the ABA inhibitory effect in floral transition was described very well in a 
study on an ABA-deficient mutant [191]. Such an inhibitory effect could be due to the modulation of DELLA protein activity [184]. Therefore, ABA is also considered a floral repressor. FLOWERING LOCUS C (FLC) is a key repressor integrator that tightly controls flowering signals [192]. FLC also mediates seed germination via genes, such as SOC1, APETALA1, and FT, making FLC an effective regulator in temperature-dependent seed germination [193]. ABFs are the bZIP TFs that are involved in ABA signaling during seed germination in plants [194,195]. Another bZIP protein, FD, mediates signals from FT at the shoot apex [196]. Overexpression of another bZIP TF, ABI5, upregulates FLC expression and delays flowering initiation. Phosphorylation of ABI5/SnRK2 during ABA signaling directly affects floral transition, and the inhibitory effect of ABI5 on floral transition disappears without phosphorylation. Transactivation of FLC expression could occur by direct binding of ABI5 to FLC promoter regions [197]. AtU2AF65b, a putative U2AF65 spliceosome, participates in ABA-mediated flowering via the regulation of the pre-mRNA splicing of $A B I 5$ and FLC [198], which indicates the positive regulation of FLC activity by ABI5 during ABA signaling. Furthermore, AtU2AF65b-mediated mRNA splicing is critical for ABA-regulated flowering transition for the control of floral transition in plants (Figure 1E).

\section{Other Aspects of ABA Signaling}

ABA transporters are also a significant part of ABA signaling, as it is important to transport ABA from its sites of synthesis to its multiple sites of action within plants. In Arabidopsis, four ABA transporters have been identified (AtABCG25, AtABCG30, AtABCG31, and AtABCG40) all of which are ATP-binding cassette transporter G subfamily members [199-202]. AtABCG25 is involved in exporting ABA from the vasculature [201], while AtABCG40 is a plasma-membrane ABA-uptake transporter in guard cells, and is necessary for timely closure of stomata in response to drought stress and seed germination $[199,200]$. AtABCG30 mediates ABA uptake into the embryo, while AtABCG31 brings about ABA secretion from the endosperm [200]. A recent study reported ABA transporter-like 1 (AhATL1) gene from peanut (Arachis hypogaea L.) whose cognate protein, AhATL1, is a member of the ATP-binding cassette transporter G subfamily and localizes to the plasma membrane [203]. The expression of both the AhATL1 transcript and the corresponding protein was upregulated by water stress and treatment with exogenous ABA. Another report suggested that in Medicago truncatula, MtABCG20 acts as an ABA exporter that influences root morphology and seed germination [204]. These data indicate that the ABA transport system plays a significant role in water deficit tolerance and growth regulation [203].

ABA signaling crosstalk occurs with other hormones that are involved in plant growth and stress response. These hormones include strigolactone, cytokinin, and karrikin. Strigolactone (SL) is a recently discovered class of phytohormone that inhibits shoot branching [205]. ABA signaling may regulate SL biosynthesis [206]. The antagonistic action of ABA and cytokinin signaling mediates drought stress response in Arabidopsis [207]. Karrikin signaling pathway seems to be upstream of ABA signaling pathway and karrikin mediates changes in ABA-related gene expression [208]. DELLA protein is important for seed germination [209]. ABA also interacts with DELLA protein when DELLA/ABI3/ABI5 complex is involved in seed germination [210].

\section{Conclusions}

It is evident that $\mathrm{ABA}$ is an important signaling compound. In stress and developmental responses in plants, ABA signaling largely depends on the SnRK family of protein kinases. ABA signaling integrates other signaling components, such as $\mathrm{Ca}^{2+}$, light, MAP kinase, SA, JA, and ET signaling, in response to environmental cues, developmental activities, and biotic stress (Figure 3). Such integration is vital for response stress and plant development; however, there are still gaps regarding to what extent and how often such integrations occur. In addition, it is important to reveal the complex ABA signaling network by adopting more integrated and more detailed genome-wide studies to identify the critical components of stress responses and developmental processes and to develop scientific tools for 
the genetic engineering of stress-tolerant and robust plants. Furthermore, it is critical to determine the role of all ABA signaling-related genes to fill any knowledge gaps about ABA signaling. In the future, studying the function of ABA signaling-related genes under different combined stress conditions and the regulation of developmental processes would offer detailed insights into the underlying mechanism of ABA signaling.

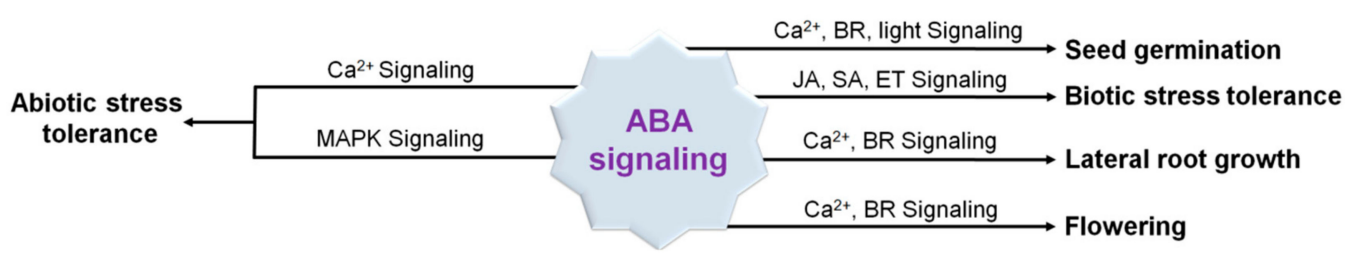

Figure 3. Integration of various signaling pathways with ABA signaling. ABA signaling plays a central role in regulating different developmental processes, including stress responses, as is evident from its interactions with calcium $\left(\mathrm{Ca}^{2+}\right)$, jasmonic acid (JA), salicylic acid (SA), brassinosteroid (BR), ethylene (ET), and MAP kinase (MAPK) signaling pathway members.

Author Contributions: M.K. and H.U.K. designed the study; M.K. wrote the manuscript with critical inputs from H.U.K. M.S.K., A.A., S.-C.L., and S.S.G. gave valuable input to this manuscript.

Funding: This work was supported by the Korea Institute of Planning and Evaluation for Technology in Food, Agriculture, Forestry, and Fisheries (IPET) (grant number 319107-4); the Next-Generation BioGreen 21 Program of the Rural Development Administration, Korea (SSAC, grant number PJ013185); and the Mid-Career Researcher Program of the National Research Foundation of Korea (grant number NRF-2017R1A2B4007096).

Conflicts of Interest: The authors declare no conflict of interest.

\section{References}

1. Seo, M.; Koshiba, T. Complex regulation of ABA biosynthesis in plants. Trends Plant Sci. 2002, 7, 41-48. [CrossRef]

2. Wang, D.L.; Gao, Z.Z.; Du, P.Y.; Xiao, W.; Tan, Q.P.; Chen, X.D.; Li, L.; Gao, D.S. Expression of ABA Metabolism-Related Genes Suggests Similarities and Differences Between Seed Dormancy and Bud Dormancy of Peach (Prunus persica). Front. Plant Sci. 2016, 6. [CrossRef] [PubMed]

3. Chandler, P.M.; Robertson, M. Gene-Expression Regulated by Abscisic-Acid and Its Relation to Stress Tolerance. Annu. Rev. Plant Biol. 1994, 45, 113-141. [CrossRef]

4. Hocking, T.J.; Hillman, J.R. Studies on the role of abscisic acid in the initiation of bud dormancy in Alnus glutinosa and Betula pubescens. Planta 1975, 125, 235-242. [CrossRef]

5. Schopfer, P.; Bajracharya, D.; Plachy, C. Control of Seed-Germination by Abscisic-Acid.1. Time Course of Action in Sinapis-Alba L. Plant Physiol. 1979, 64, 822-827. [CrossRef]

6. Hiron, R.; Wright, S. The role of endogenous abscisic acid in the response of plants to stress. J. Exp. Bot. 1973, 24, 769-780. [CrossRef]

7. Ohkuma, K.; Smith, O.E.; Lyon, J.L.; Addicott, F.T. Abscisin 2, an Abscission-Accelerating Substance from Young Cotton Fruit. Science 1963, 142, 1592-1593. [CrossRef]

8. Addicott, F.T.; Lyon, J.L.; Ohkuma, K.; Thiessen, W.E.; Carns, H.R.; Smith, O.E.; Cornforth, J.W.; Milborrow, B.V.; Ryback, G.; Wareing, P.F. Abscisic Acid-A New Name for Abscisin 2 (Dormin). Science 1968, 159, 1493. [CrossRef]

9. Aharoni, N.; Benyehoshua, S.; Richmond, A.E. Effects of Water Stress on Ethylene Emanation and Endogenous Content of Abscisic-Acid and Gibberellins in Detached Lettuce Leaves (Lactuca-Sativa-L). Israel J. Bot. 1975, $24,55$.

10. Davies, W.J.; Kozlowski, T.T. Effects of Applied Abscisic-Acid and Plant Water Stress on Transpiration of Woody Angiosperms. For. Sci. 1975, 21, 191-195.

11. Hartung, W. Effect of Water Stress on Transport of [2-C-14]Abscisic Acid in Intact Plants of Phaseolus-Coccineus-L. Oecologia 1976, 26, 177-183. [CrossRef] [PubMed] 
12. Hoad, G.V. Effect of Water Stress on Abscisic-Acid Levels in White Lupin (Lupinus-Albus L) Fruit, Leaves and Phloem Exudate. Planta 1978, 142, 287-290. [CrossRef] [PubMed]

13. Ismail, M.M.; Storey, J.B. Effect of Water Stress on Accumulation of Abscisic-Acid in Pecan Leaves (Carya-Illinoensis-(Wang) K-Koch). Hortscience 1978, 13, 345.

14. Nordin, A. Effects of Water Stress and Abscisic-Acid on Transpiration Regulation in Wheat. Physiol. Plant. 1976, 38, 233-239. [CrossRef]

15. Quarrie, S.A.; Jones, H.G. Effects of Abscisic-Acid and Water Stress on Development and Morphology of Wheat. J. Exp. Bot. 1977, 28, 192-203. [CrossRef]

16. Walton, D.C.; Harrison, M.A.; Cote, P. Effects of Water Stress on Abscisic-Acid Levels and Metabolism in Roots of Phaseolus-Vulgaris-L and Other Plants. Planta 1976, 131, 141-144. [CrossRef]

17. Willmer, C.M.; Don, R.; Parker, W. Levels of Short-Chain Fatty-Acids and of Abscisic-Acid in Water-Stressed and Non-Stressed Leaves and Their Effects on Stomata in Epidermal Strips and Excised Leaves. Planta 1978, 139, 281-287. [CrossRef]

18. Addicott, F.T.; Lyon, J.L. Citation Classic-Physiology of Abscisic-Acid and Related Substances. Curr. Contents Agric. Biol. Environ. Sci. 1979, 18, 12.

19. Pourtau, N.; Mares, M.; Purdy, S.; Quentin, N.; Ruel, A.; Wingler, A. Interactions of abscisic acid and sugar signalling in the regulation of leaf senescence. Planta 2004, 219, 765-772. [CrossRef]

20. Rivero, R.M.; Kojima, M.; Gepstein, A.; Sakakibara, H.; Mittler, R.; Gepstein, S.; Blumwald, E. Delayed leaf senescence induces extreme drought tolerance in a flowering plant. Proc. Natl. Acad. Sci. USA 2007, 104, 19631-19636. [CrossRef]

21. Carrera, E.; Holman, T.; Medhurst, A.; Dietrich, D.; Footitt, S.; Theodoulou, F.L.; Holdsworth, M.J. Seed after-ripening is a discrete developmental pathway associated with specific gene networks in Arabidopsis. Plant J. 2008, 53, 214-224. [CrossRef] [PubMed]

22. Ko, D.; Helariutta, Y. Shoot-Root Communication in Flowering Plants. Curr. Biol. 2017, 27, R973-R978. [CrossRef] [PubMed]

23. de Torres-Zabala, M.; Truman, W.; Bennett, M.H.; Lafforgue, G.; Mansfield, J.W.; Rodriguez Egea, P.; Bogre, L.; Grant, M. Pseudomonas syringae pv. tomato hijacks the Arabidopsis abscisic acid signalling pathway to cause disease. EMBO J. 2007, 26, 1434-1443. [CrossRef] [PubMed]

24. Asselbergh, B.; De Vleesschauwer, D.; Hofte, M. Global switches and fine-tuning - ABA modulates plant pathogen defense. Mol. Plant Microbe Interact. 2008, 21, 709-719. [CrossRef]

25. Stec, N.; Banasiak, J.; Jasinski, M. Abscisic acid-An overlooked player in plant-microbe symbioses formation? Acta Biochim. Pol. 2016, 63, 53-58. [CrossRef]

26. Sakthivel, P.; Sharma, N.; Klahn, P.; Gereke, M.; Bruder, D. Abscisic Acid: A Phytohormone and Mammalian Cytokine as Novel Pharmacon with Potential for Future Development into Clinical Applications. Curr. Med. Chem. 2016, 23, 1549-1570. [CrossRef]

27. Spence, C.A.; Lakshmanan, V.; Donofrio, N.; Bais, H.P. Crucial Roles of Abscisic Acid Biogenesis in Virulence of Rice Blast Fungus Magnaporthe oryzae. Front. Plant Sci. 2015, 6, 1082. [CrossRef]

28. Siewers, V.; Kokkelink, L.; Smedsgaard, J.; Tudzynski, P. Identification of an abscisic acid gene cluster in the grey mold Botrytis cinerea. Appl. Environ. Microb. 2006, 72, 4619-4626. [CrossRef]

29. Cohen, A.C.; Bottini, R.; Piccoli, P.N. Azospirillum brasilense Sp 245 produces ABA in chemically-defined culture medium and increases ABA content in arabidopsis plants. Plant Growth Regul. 2008, 54, 97-103. [CrossRef]

30. Goel, A.K.; Lundberg, D.; Torres, M.A.; Matthews, R.; Akimoto-Tomiyama, C.; Farmer, L.; Dangl, J.L.; Grant, S.R. The Pseudomonas syringae type III effector HopAM1 enhances virulence on water-stressed plants. Mol. Plant Microbe Interact. 2008, 21, 361-370. [CrossRef]

31. Jang, J.Y.; Kim, D.G.; Kim, Y.O.; Kim, J.S.; Kang, H.S. An expression analysis of a gene family encoding plasma membrane aquaporins in response to abiotic stresses in Arabidopsis thaliana. Plant Mol. Biol. 2004, 54, 713-725. [CrossRef] [PubMed]

32. Cui, J.; Li, P.; Li, G.; Xu, F.; Zhao, C.; Li, Y.H.; Yang, Z.N.; Wang, G.; Yu, Q.B.; Li, Y.X.; et al. AtPID: Arabidopsis thaliana protein interactome database-An integrative platform for plant systems biology. Nucleic Acids Res. 2008, 36, D999-D1008. [CrossRef] [PubMed]

33. Kaldenhoff, R.; Ribas-Carbo, M.; Flexas, J.; Lovisolo, C.; Heckwolf, M.; Uehlein, N. Aquaporins and plant water balance. Plant Cell Environ. 2008, 31, 658-666. [CrossRef] [PubMed] 
34. Finkelstein, R.R. Studies of abscisic acid perception finally flower. Plant Cell 2006, 18, 786-791. [CrossRef] [PubMed]

35. Grill, E.; Christmann, A. A plant receptor with a big family. Science 2007, 315, 1676-1677. [CrossRef] [PubMed]

36. Razem, F.A.; El-Kereamy, A.; Abrams, S.R.; Hill, R.D. The RNA-binding protein FCA is an abscisic acid receptor. Nature 2006, 439, 290-294. [CrossRef]

37. Verslues, P.E.; Zhu, J.K. New developments in abscisic acid perception and metabolism. Curr. Opin. Plant Biol. 2007, 10, 447-452. [CrossRef]

38. McCourt, P.; Creelman, R. The ABA receptors-We report you decide. Curr. Opin. Plant Biol. 2008, 11, 474-478. [CrossRef]

39. Wang, X.F.; Zhang, D.P. Abscisic acid receptors: Multiple signal-perception sites. Ann. Bot. 2008, 101, 311-317. [CrossRef]

40. Guo, J.J.; Yang, X.H.; Weston, D.J.; Chen, J.G. Abscisic Acid Receptors: Past, Present and Future. J. Integr. Plant Biol. 2011, 53, 469-479. [CrossRef]

41. Ma, Y.; Szostkiewicz, I.; Korte, A.; Moes, D.; Yang, Y.; Christmann, A.; Grill, E. Regulators of PP2C Phosphatase Activity Function as Abscisic Acid Sensors. Science 2009, 324, 1064-1068. [CrossRef] [PubMed]

42. Park, S.Y.; Fung, P.; Nishimura, N.; Jensen, D.R.; Fujii, H.; Zhao, Y.; Lumba, S.; Santiago, J.; Rodrigues, A.; Chow, T.F.F.; et al. Abscisic Acid Inhibits Type 2C Protein Phosphatases via the PYR/PYL Family of START Proteins. Science 2009, 324, 1068-1071. [CrossRef] [PubMed]

43. Nishimura, N.; Sarkeshik, A.; Nito, K.; Park, S.Y.; Wang, A.; Carvalho, P.C.; Lee, S.; Caddell, D.F.; Cutler, S.R.; Chory, J.; et al. PYR/PYL/RCAR family members are major in-vivo ABI1 protein phosphatase 2C-interacting proteins in Arabidopsis. Plant J. 2010, 61, 290-299. [CrossRef] [PubMed]

44. Santiago, J.; Rodrigues, A.; Saez, A.; Rubio, S.; Antoni, R.; Dupeux, F.; Park, S.Y.; Marquez, J.A.; Cutler, S.R.; Rodriguez, P.L. Modulation of drought resistance by the abscisic acid receptor PYL5 through inhibition of clade A PP2Cs. Plant J. 2009, 60, 575-588. [CrossRef] [PubMed]

45. Pennisi, E. Breakthrough of the year: The runners-up. Science 2009, 326, 1600-1607. [CrossRef]

46. Adler, E.M. 2009: Signaling breakthroughs of the year. Sci. Signal. 2010, 3, eg1. [CrossRef]

47. Melcher, K.; Ng, L.M.; Zhou, X.E.; Soon, F.F.; Xu, Y.; Suino-Powell, K.M.; Park, S.Y.; Weiner, J.J.; Fujii, H.; Chinnusamy, V.; et al. A gate-latch-lock mechanism for hormone signalling by abscisic acid receptors. Nature 2009, 462, 602-608. [CrossRef]

48. Miyazono, K.; Miyakawa, T.; Sawano, Y.; Kubota, K.; Kang, H.J.; Asano, A.; Miyauchi, Y.; Takahashi, M.; Zhi, Y.H.; Fujita, Y.; et al. Structural basis of abscisic acid signalling. Nature 2009, 462, 609-679. [CrossRef]

49. Ng, L.M.; Soon, F.F.; Zhou, X.E.; West, G.M.; Kovach, A.; Suino-Powell, K.M.; Chalmers, M.J.; Li, J.; Yong, E.L.; Zhu, J.K.; et al. Structural basis for basal activity and autoactivation of abscisic acid (ABA) signaling SnRK2 kinases. Proc. Natl. Acad. Sci. USA 2011, 108, 21259-21264. [CrossRef]

50. Yin, P.; Fan, H.; Hao, Q.; Yuan, X.Q.; Wu, D.; Pang, Y.X.; Yan, C.Y.; Li, W.Q.; Wang, J.W.; Yan, N. Structural insights into the mechanism of abscisic acid signaling by PYL proteins. Nat. Struct. Mol. Biol. 2009, 16, 1230-1242. [CrossRef]

51. Soon, F.F.; Ng, L.M.; Zhou, X.E.; West, G.M.; Kovach, A.; Tan, M.H.E.; Suino-Powell, K.M.; He, Y.Z.; Xu, Y.; Chalmers, M.J.; et al. Molecular Mimicry Regulates ABA Signaling by SnRK2 Kinases and PP2C Phosphatases. Science 2012, 335, 85-88. [CrossRef] [PubMed]

52. Suzuki, M.; McCarty, D.R. Functional symmetry of the B3 network controlling seed development. Curr. Opin. Plant Biol. 2008, 11, 548-553. [CrossRef] [PubMed]

53. Edel, K.H.; Kudla, J. Integration of calcium and ABA signaling. Curr. Opin. Plant Biol. 2016, 33, 83-91. [CrossRef] [PubMed]

54. Sreenivasulu, N.; Harshavardhan, V.T.; Govind, G.; Seiler, C.; Kohli, A. Contrapuntal role of ABA: Does it mediate stress tolerance or plant growth retardation under long-term drought stress? Gene 2012, 506, 265-273. [CrossRef]

55. Nakashima, K.; Yamaguchi-Shinozaki, K. ABA signaling in stress-response and seed development. Plant Cell Rep. 2013, 32, 959-970. [CrossRef]

56. Yoshida, T.; Mogami, J.; Yamaguchi-Shinozaki, K. ABA-dependent and ABA-independent signaling in response to osmotic stress in plants. Curr. Opin. Plant Biol. 2014, 21, 133-139. [CrossRef] 
57. Liu, Y.K. Roles of mitogen-activated protein kinase cascades in ABA signaling. Plant Cell Rep. 2012, 31, 1-12. [CrossRef]

58. de Zelicourt, A.; Colcombet, J.; Hirt, H. The Role of MAPK Modules and ABA during Abiotic Stress Signaling. Trends Plant Sci. 2016, 21, 677-685. [CrossRef]

59. Vishwakarma, K.; Upadhyay, N.; Kumar, N.; Yadav, G.; Singh, J.; Mishra, R.K.; Kumar, V.; Verma, R.; Upadhyay, R.G.; Pandey, M.; et al. Abscisic Acid Signaling and Abiotic Stress Tolerance in Plants: A Review on Current Knowledge and Future Prospects. Front. Plant Sci. 2017, 8, 161. [CrossRef]

60. Yu, F.; Wu, Y.; Xie, Q. Ubiquitin-Proteasome System in ABA Signaling: From Perception to Action. Mol. Plant 2016, 9, 21-33. [CrossRef]

61. Vierstra, R.D. The ubiquitin/26S proteasome pathway, the complex last chapter in the life of many plant proteins. Trends Plant Sci. 2003, 8, 135-142. [CrossRef]

62. Smalle, J.; Vierstra, R.D. The ubiquitin $26 S$ proteasome proteolytic pathway. Annu. Rev. Plant Biol. 2004, 55, 555-590. [CrossRef]

63. Bueso, E.; Rodriguez, L.; Lorenzo-Orts, L.; Gonzalez-Guzman, M.; Sayas, E.; Munoz-Bertomeu, J.; Ibanez, C.; Serrano, R.; Rodriguez, P.L. The single-subunit RING-type E3 ubiquitin ligase RSL1 targets PYL4 and PYR1 ABA receptors in plasma membrane to modulate abscisic acid signaling. Plant J. 2014, 80, 1057-1071. [CrossRef]

64. Irigoyen, M.L.; Iniesto, E.; Rodriguez, L.; Puga, M.I.; Yanagawa, Y.; Pick, E.; Strickland, E.; Paz-Ares, J.; Wei, N.; De Jaeger, G.; et al. Targeted Degradation of Abscisic Acid Receptors Is Mediated by the Ubiquitin Ligase Substrate Adaptor DDA1 in Arabidopsis. Plant Cell 2014, 26, 712-728. [CrossRef]

65. Kong, L.Y.; Cheng, J.K.; Zhu, Y.J.; Ding, Y.L.; Meng, J.J.; Chen, Z.Z.; Xie, Q.; Guo, Y.; Li, J.G.; Yang, S.H.; et al. Degradation of the ABA co-receptor ABI1 by PUB12/13 U-box E3 ligases. Nat. Commun. 2015, 6, 8630. [CrossRef]

66. Seo, J.S.; Zhao, P.Z.; Jung, C.; Chua, N.H. PLANT U-BOX PROTEIN 10 negatively regulates abscisic acid response in Arabidopsis. Appl. Biol. Chem. 2019, 62, 39. [CrossRef]

67. Lyzenga, W.J.; Liu, H.X.; Schofield, A.; Muise-Hennessey, A.; Stone, S.L. Arabidopsis CIPK26 interacts with KEG, components of the ABA signalling network and is degraded by the ubiquitin-proteasome system. J. Exp. Bot. 2013, 64, 2779-2791. [CrossRef]

68. Stone, S.L.; Williams, L.A.; Farmer, L.M.; Vierstra, R.D.; Callis, J. KEEP ON GOING, a RING E3 ligase essential for Arabidopsis growth and development, is involved in abscisic acid signaling. Plant Cell 2006, 18, 3415-3428. [CrossRef]

69. Liu, H.X.; Stone, S.L. Abscisic Acid Increases Arabidopsis ABI5 Transcription Factor Levels by Promoting KEG E3 Ligase Self-Ubiquitination and Proteasomal Degradation. Plant Cell 2010, 22, 2630-2641. [CrossRef]

70. Cheng, M.C.; Liao, P.M.; Kuo, W.W.; Lin, T.P. The Arabidopsis ETHYLENE RESPONSE FACTOR1 Regulates Abiotic Stress-Responsive Gene Expression by Binding to Different cis-Acting Elements in Response to Different Stress Signals. Plant Physiol. 2013, 162, 1566-1582. [CrossRef]

71. Pick, E.; Lau, O.S.; Tsuge, T.; Menon, S.; Tong, Y.C.; Dohmae, N.; Plafker, S.M.; Deng, X.W.; Wei, N. Mammalian DET1 regulates Cul4A activity and forms stable complexes with E2 ubiquitin-conjugating enzymes. Mol. Cell. Biol. 2007, 27, 4708-4719. [CrossRef] [PubMed]

72. Lee, J.H.; Yoon, H.J.; Terzaghi, W.; Martinez, C.; Dai, M.Q.; Li, J.G.; Byun, M.O.; Deng, X.W. DWA1 and DWA2, Two Arabidopsis DWD Protein Components of CUL4-Based E3 Ligases, Act Together as Negative Regulators in ABA Signal Transduction. Plant Cell 2010, 22, 1716-1732. [CrossRef] [PubMed]

73. Seo, K.I.; Lee, J.H.; Nezames, C.D.; Zhong, S.W.; Song, E.; Byun, M.O.; Deng, X.W. ABD1 Is an Arabidopsis DCAF Substrate Receptor for CUL4-DDB1-Based E3 Ligases That Acts as a Negative Regulator of Abscisic Acid Signaling. Plant Cell 2014, 26, 695-711. [CrossRef] [PubMed]

74. Kurup, S.; Jones, H.D.; Holdsworth, M.J. Interactions of the developmental regulator ABI3 with proteins identified from developing Arabidopsis seeds. Plant J. 2000, 21, 143-155. [CrossRef] [PubMed]

75. Nagamune, K.; Hicks, L.M.; Fux, B.; Brossier, F.; Chini, E.N.; Sibley, L.D. Abscisic acid controls calcium-dependent egress and development in Toxoplasma gondii. Nature 2008, 451, 207-U211. [CrossRef] [PubMed]

76. Kumar, M.; Lee, S.C.; Kim, J.Y.; Kim, S.J.; Aye, S.S.; Kim, S.R. Over-expression of dehydrin gene, OsDhn1, improves drought and salt stress tolerance through scavenging of reactive oxygen species in rice (Oryza sativa L.). J. Plant Biol. 2014, 57, 383-393. [CrossRef] 
77. Kumar, M. Crop plants and abiotic stresses. J. Biomol. Res. Ther. 2013, 3, 1000e125. [CrossRef]

78. Kumar, M.; Kesawat, M.S. Mechanism of Salt Stress Tolerance and Pathways in Crop Plants. In Metabolic Adaptations in Plants During Abiotic Stress; CRC Press: Boca Raton, FL, USA, 2018; pp. 27-44.

79. Kumar, M.; Gho, Y.S.; Jung, K.H.; Kim, S.R. Genome-Wide Identification and Analysis of Genes, Conserved between japonica and indica Rice Cultivars, that Respond to Low-Temperature Stress at the Vegetative Growth Stage. Front. Plant Sci. 2017, 8, 1120. [CrossRef]

80. Kwak, J.M.; Mori, I.C.; Pei, Z.M.; Leonhardt, N.; Torres, M.A.; Dangl, J.L.; Bloom, R.E.; Bodde, S.; Jones, J.D.G.; Schroeder, J.I. NADPH oxidase AtrbohD and AtrbohF genes function in ROS-dependent ABA signaling in Arabidopsis. EMBO J. 2003, 22, 2623-2633. [CrossRef]

81. Munemasa, S.; Muroyama, D.; Nagahashi, H.; Nakamura, Y.; Mori, I.C.; Murata, Y. Regulation of reactive oxygen species-mediated abscisic acid signaling in guard cells and drought tolerance by glutathione. Front. Plant Sci. 2013, 4, 472. [CrossRef]

82. Mitula, F.; Tajdel, M.; Ciesla, A.; Kasprowicz-Maluski, A.; Kulik, A.; Babula-Skowronska, D.; Michalak, M.; Dobrowolska, G.; Sadowski, J.; Ludwikow, A. Arabidopsis ABA-Activated Kinase MAPKKK18 is Regulated by Protein Phosphatase 2C ABI1 and the Ubiquitin-Proteasome Pathway. Plant Cell Physiol. 2015, 56, 2351-2367. [CrossRef] [PubMed]

83. Irving, H.R.; Gehring, C.A.; Parish, R.W. Changes in Cytosolic Ph and Calcium of Guard-Cells Precede Stomatal Movements. Proc. Natl. Acad. Sci. USA 1992, 89, 1790-1794. [CrossRef] [PubMed]

84. Brandt, B.; Munemasa, S.; Wang, C.; Nguyen, D.; Yong, T.M.; Yang, P.G.; Poretsky, E.; Belknap, T.F.; Waadt, R.; Aleman, F.; et al. Calcium specificity signaling mechanisms in abscisic acid signal transduction in Arabidopsis guard cells. Elife 2015, 4, e03599. [CrossRef]

85. Clapham, D.E. Calcium signaling. Cell 1995, 80, 259-268. [CrossRef]

86. Clapham, D.E. Calcium signaling. Cell 2007, 131, 1047-1058. [CrossRef]

87. Kudla, J.; Batistic, O.; Hashimoto, K. Calcium Signals: The Lead Currency of Plant Information Processing. Plant Cell 2010, 22, 541-563. [CrossRef]

88. Edel, K.H.; Kudla, J. Increasing complexity and versatility: How the calcium signaling toolkit was shaped during plant land colonization. Cell Calcium 2015, 57, 231-246. [CrossRef]

89. Hashimoto, K.; Kudla, J. Calcium decoding mechanisms in plants. Biochimie 2011, 93, 2054-2059. [CrossRef]

90. Batistic, O.; Kudla, J. Analysis of calcium signaling pathways in plants. Biochim. Biophys. Acta Gen. Subj. 2012, 1820, 1283-1293. [CrossRef]

91. Kudla, J.; Xu, Q.; Harter, K.; Gruissem, W.; Luan, S. Genes for calcineurin B-like proteins in Arabidopsis are differentially regulated by stress signals. Proc. Natl. Acad. Sci. USA 1999, 96, 4718-4723. [CrossRef]

92. Shi, J.R.; Kim, K.N.; Ritz, O.; Albrecht, V.; Gupta, R.; Harter, K.; Luan, S.; Kudla, J. Novel protein kinases associated with calcineurin B-like calcium sensors in Arabidopsis. Plant Cell 1999, 11, 2393-2405. [CrossRef] [PubMed]

93. Steinhorst, L.; Kudla, J. Signaling in cells and organisms-Calcium holds the line. Curr. Opin. Plant Biol. 2014, 22, 14-21. [CrossRef]

94. Liese, A.; Romeis, T. Biochemical regulation of in vivo function of plant calcium-dependent protein kinases (CDPK). Biochim. Biophys. Acta Mol. Cell Res. 2013, 1833, 1582-1589. [CrossRef] [PubMed]

95. Maierhofer, T.; Diekmann, M.; Offenborn, J.N.; Lind, C.; Bauer, H.; Hashimoto, K.; Al-Rasheid, K.A.S.; Luan, S.; Kudla, J.; Geiger, D.; et al. Site- and kinase-specific phosphorylation-mediated activation of SLAC1, a guard cell anion channel stimulated by abscisic acid. Sci. Signal. 2014, 7, ra86. [CrossRef] [PubMed]

96. Dubiella, U.; Seybold, H.; Durian, G.; Komander, E.; Lassig, R.; Witte, C.P.; Schulze, W.X.; Romeis, T. Calcium-dependent protein kinase/NADPH oxidase activation circuit is required for rapid defense signal propagation. Proc. Natl. Acad. Sci. USA 2013, 110, 8744-8749. [CrossRef]

97. Boudsocq, M.; Sheen, J. CDPKs in immune and stress signaling. Trends Plant Sci. 2013, 18, 30-40. [CrossRef]

98. Acharya, B.R.; Jeon, B.W.; Zhang, W.; Assmann, S.M. Open Stomata 1 (OST1) is limiting in abscisic acid responses of Arabidopsis guard cells. New Phytol. 2013, 200, 1049-1063. [CrossRef]

99. Mustilli, A.C.; Merlot, S.; Vavasseur, A.; Fenzi, F.; Giraudat, J. Arabidopsis OST1 protein kinase mediates the regulation of stomatal aperture by abscisic acid and acts upstream of reactive oxygen species production. Plant Cell 2002, 14, 3089-3099. [CrossRef] 
100. Yoshida, R.; Umezawa, T.; Mizoguchi, T.; Takahashi, S.; Takahashi, F.; Shinozaki, K. The regulatory domain of SRK2E/OST1/SnRK2.6 interacts with ABI1 and integrates abscisic acid (ABA) and osmotic stress signals controlling stomatal closure in Arabidopsis. J. Biol. Chem. 2006, 281, 5310-5318. [CrossRef]

101. Fujii, H.; Chinnusamy, V.; Rodrigues, A.; Rubio, S.; Antoni, R.; Park, S.Y.; Cutler, S.R.; Sheen, J.; Rodriguez, P.L.; Zhu, J.K. In vitro reconstitution of an abscisic acid signalling pathway. Nature 2009, 462, 660-664. [CrossRef]

102. Zhou, X.; Hao, H.; Zhang, Y.; Bai, Y.; Zhu, W.; Qin, Y.; Yuan, F.; Zhao, F.; Wang, M.; Hu, J.; et al. PKS5/CIPK11, a SnRK3-Type Protein Kinase, is Important for ABA Responses in Arabidopsis through Phosphorylation of ABI5. Plant Physiol. 2015, 114.255455. [CrossRef] [PubMed]

103. Zhu, S.Y.; Yu, X.C.; Wang, X.J.; Zhao, R.; Li, Y.; Fan, R.C.; Shang, Y.; Du, S.Y.; Wang, X.F.; Wu, F.Q.; et al. Two calcium-dependent protein kinases, CPK4 and CPK11, regulate abscisic acid signal transduction in Arabidopsis. Plant Cell 2007, 19, 3019-3036. [CrossRef] [PubMed]

104. Lee, S.C.; Lan, W.; Buchanan, B.B.; Luan, S. A protein kinase-phosphatase pair interacts with an ion channel to regulate ABA signaling in plant guard cells. Proc. Natl. Acad. Sci. USA 2009, 106, 21419-21424. [CrossRef] [PubMed]

105. Lan, W.Z.; Lee, S.C.; Che, Y.F.; Jiang, Y.Q.; Luan, S. Mechanistic analysis of AKT1 regulation by the CBL-CIPK-PP2CA interactions. Mol. Plant 2011, 4, 527-536. [CrossRef] [PubMed]

106. Xu, J.; Li, H.D.; Chen, L.Q.; Wang, Y.; Liu, L.L.; He, L.; Wu, W.H. A protein kinase, interacting with two calcineurin B-like proteins, regulates K+ transporter AKT1 in Arabidopsis. Cell 2006, 125, 1347-1360. [CrossRef] [PubMed]

107. Cherel, I.; Michard, E.; Platet, N.; Mouline, K.; Alcon, C.; Sentenac, H.; Thibaud, J.B. Physical and functional interaction of the Arabidopsis $\mathrm{K}(+)$ channel AKT2 and phosphatase AtPP2CA. Plant Cell 2002, 14, 1133-1146. [CrossRef] [PubMed]

108. Held, K.; Pascaud, F.; Eckert, C.; Gajdanowicz, P.; Hashimoto, K.; Corratge-Faillie, C.; Offenborn, J.N.; Lacombe, B.; Dreyer, I.; Thibaud, J.B.; et al. Calcium-dependent modulation and plasma membrane targeting of the AKT2 potassium channel by the CBL4/CIPK6 calcium sensor/protein kinase complex. Cell Res 2011, 21, 1116-1130. [CrossRef]

109. Ronzier, E.; Corratge-Faillie, C.; Sanchez, F.; Prado, K.; Briere, C.; Leonhardt, N.; Thibaud, J.B.; Xiong, T.C. CPK13, a noncanonical Ca2+-dependent protein kinase, specifically inhibits KAT2 and KAT1 shaker K+ channels and reduces stomatal opening. Plant Physiol 2014, 166, 314-326. [CrossRef]

110. Locascio, A.; Marques, M.C.; Garcia-Martinez, G.; Corratge-Faillie, C.; Andres-Colas, N.; Rubio, L.; Fernandez, J.A.; Very, A.A.; Mulet, J.M.; Yenush, L. BCL2-ASSOCIATED ATHANOGENE4 Regulates the KAT1 Potassium Channel and Controls Stomatal Movement. Plant Physiol 2019, 181, 1277-1294. [CrossRef]

111. Leran, S.; Edel, K.H.; Pervent, M.; Hashimoto, K.; Corratge-Faillie, C.; Offenborn, J.N.; Tillard, P.; Gojon, A.; Kudla, J.; Lacombe, B. Nitrate sensing and uptake in Arabidopsis are enhanced by ABI2, a phosphatase inactivated by the stress hormone abscisic acid. Sci. Signal 2015, 8, ra43. [CrossRef]

112. Ho, C.H.; Lin, S.H.; Hu, H.C.; Tsay, Y.F. CHL1 functions as a nitrate sensor in plants. Cell 2009, 138, $1184-1194$. [CrossRef] [PubMed]

113. Liu, X.; Peng, H.; Liao, W.; Luo, A.; Cai, M.; He, J.; Zhang, X.; Luo, Z.; Jiang, H.; Xu, L. MiR-181a/b induce the growth, invasion, and metastasis of neuroblastoma cells through targeting ABI1. Mol. Carcinog. 2018, 57, 1237-1250. [CrossRef] [PubMed]

114. Hedrich, R.; Geiger, D. Biology of SLAC1-type anion channels - from nutrient uptake to stomatal closure. New Phytol. 2017, 216, 46-61. [CrossRef] [PubMed]

115. Sirichandra, C.; Gu, D.; Hu, H.C.; Davanture, M.; Lee, S.; Djaoui, M.; Valot, B.; Zivy, M.; Leung, J.; Merlot, S.; et al. Phosphorylation of the Arabidopsis AtrbohF NADPH oxidase by OST1 protein kinase. Febs Lett. 2009, 583, 2982-2986. [CrossRef] [PubMed]

116. Drerup, M.M.; Schlucking, K.; Hashimoto, K.; Manishankar, P.; Steinhorst, L.; Kuchitsu, K.; Kudla, J. The Calcineurin B-Like Calcium Sensors CBL1 and CBL9 Together with Their Interacting Protein Kinase CIPK26 Regulate the Arabidopsis NADPH Oxidase RBOHF. Mol. Plant 2013, 6, 559-569. [CrossRef] [PubMed]

117. Zheng, X.; Kang, S.; Jing, Y.; Ren, Z.; Li, L.; Zhou, J.M.; Berkowitz, G.; Shi, J.; Fu, A.; Lan, W.; et al. Danger-Associated Peptides Close Stomata by OST1-Independent Activation of Anion Channels in Guard Cells. Plant Cell 2018, 30, 1132-1146. [CrossRef] [PubMed] 
118. Demir, F.; Horntrich, C.; Blachutzik, J.O.; Scherzer, S.; Reinders, Y.; Kierszniowska, S.; Schulze, W.X.; Harms, G.S.; Hedrich, R.; Geiger, D.; et al. Arabidopsis nanodomain-delimited ABA signaling pathway regulates the anion channel SLAH3. Proc. Natl. Acad. Sci. USA 2013, 110, 8296-8301. [CrossRef]

119. Geiger, D.; Maierhofer, T.; Al-Rasheid, K.A.; Scherzer, S.; Mumm, P.; Liese, A.; Ache, P.; Wellmann, C.; Marten, I.; Grill, E.; et al. Stomatal closure by fast abscisic acid signaling is mediated by the guard cell anion channel SLAH3 and the receptor RCAR1. Sci. Signal 2011, 4, ra32. [CrossRef]

120. Lee, S.C.; Lim, C.W.; Lan, W.Z.; He, K.; Luan, S. ABA Signaling in Guard Cells Entails a Dynamic Protein-Protein Interaction Relay from the PYL-RCAR Family Receptors to Ion Channels. Mol. Plant 2013, 6, 528-538. [CrossRef]

121. Sato, A.; Sato, Y.; Fukao, Y.; Fujiwara, M.; Umezawa, T.; Shinozaki, K.; Hibi, T.; Taniguchi, M.; Miyake, H.; Goto, D.B.; et al. Threonine at position 306 of the KAT1 potassium channel is essential for channel activity and is a target site for ABA-activated SnRK2/OST1/SnRK2.6 protein kinase. Biochem. J. 2009, 424, 439-448. [CrossRef]

122. Mori, I.C.; Murata, Y.; Yang, Y.Z.; Munemasa, S.; Wang, Y.F.; Andreoli, S.; Tiriac, H.; Alonso, J.M.; Harper, J.F.; Ecker, J.R.; et al. CDPKs CPK6 and CPK3 function in ABA regulation of guard cell S-type anion- and Ca2+-permeable channels and stomatal closure. PLoS Biol. 2006, 4, 1749-1762. [CrossRef] [PubMed]

123. Geiger, D.; Scherzer, S.; Mumm, P.; Stange, A.; Marten, I.; Bauer, H.; Ache, P.; Matschi, S.; Liese, A.; Al-Rasheid, K.A.S.; et al. Activity of guard cell anion channel SLAC1 is controlled by drought-stress signaling kinase-phosphatase pair. Proc. Natl. Acad. Sci. USA 2009, 106, 21425-21430. [CrossRef] [PubMed]

124. Geiger, D.; Scherzer, S.; Mumm, P.; Marten, I.; Ache, P.; Matschi, S.; Liese, A.; Wellmann, C.; Al-Rasheid, K.A.S.; Grill, E.; et al. Guard cell anion channel SLAC1 is regulated by CDPK protein kinases with distinct Ca2+ affinities. Proc. Natl. Acad. Sci. USA 2010, 107, 8023-8028. [CrossRef] [PubMed]

125. Brandt, B.; Brodsky, D.E.; Xue, S.W.; Negi, J.; Iba, K.; Kangasjarvi, J.; Ghassemian, M.; Stephan, A.B.; Hu, H.H.; Schroeder, J.I. Reconstitution of abscisic acid activation of SLAC1 anion channel by CPK6 and OST1 kinases and branched ABI1 PP2C phosphatase action. Proc. Natl. Acad. Sci. USA 2012, 109, 10593-10598. [CrossRef]

126. Kulik, A.; Wawer, I.; Krzywinska, E.; Bucholc, M.; Dobrowolska, G. SnRK2 Protein Kinases-Key Regulators of Plant Response to Abiotic Stresses. Omics 2011, 15, 859-872. [CrossRef]

127. Fujita, Y.; Fujita, M.; Shinozaki, K.; Yamaguchi-Shinozaki, K. ABA-mediated transcriptional regulation in response to osmotic stress in plants. J. Plant Res. 2011, 124, 509-525. [CrossRef]

128. Tuteja, N. Abscisic Acid and abiotic stress signaling. Plant Signal. Behav. 2007, 2, 135-138. [CrossRef]

129. Yamaguchi-Shinozaki, K.; Shinozaki, K. Transcriptional regulatory networks in cellular responses and tolerance to dehydration and cold stresses. Annu. Rev. Plant Biol. 2006, 57, 781-803. [CrossRef]

130. Nakashima, K.; Ito, Y.; Yamaguchi-Shinozaki, K. Transcriptional Regulatory Networks in Response to Abiotic Stresses in Arabidopsis and Grasses. Plant Physiol. 2009, 149, 88-95. [CrossRef]

131. Maruyama, K.; Todaka, D.; Mizoi, J.; Yoshida, T.; Kidokoro, S.; Matsukura, S.; Takasaki, H.; Sakurai, T.; Yamamoto, Y.Y.; Yoshiwara, K.; et al. Identification of Cis-Acting Promoter Elements in Cold- and Dehydration-Induced Transcriptional Pathways in Arabidopsis, Rice, and Soybean. DNA Res. 2012, 19, 37-49. [CrossRef]

132. Nakabayashi, K.; Okamoto, M.; Koshiba, T.; Kamiya, Y.; Nambara, E. Genome-wide profiling of stored mRNA in Arabidopsis thaliana seed germination: Epigenetic and genetic regulation of transcription in seed. Plant J. 2005, 41, 697-709. [CrossRef] [PubMed]

133. Fujita, Y.; Fujita, M.; Satoh, R.; Maruyama, K.; Parvez, M.M.; Seki, M.; Hiratsu, K.; Ohme-Takagi, M.; Shinozaki, K.; Yamaguchi-Shinozaki, K. AREB1 is a transcription activator of novel ABRE-dependent ABA signaling that enhances drought stress tolerance in Arabidopsis. Plant Cell 2005, 17, 3470-3488. [CrossRef] [PubMed]

134. Kang, J.Y.; Choi, H.I.; Im, M.Y.; Kim, S.Y. Arabidopsis basic leucine zipper proteins that mediate stress-responsive abscisic acid signaling. Plant Cell 2002, 14, 343-357. [CrossRef] [PubMed]

135. Kim, S.; Kang, J.Y.; Cho, D.I.; Park, J.H.; Kim, S.Y. ABF2, an ABRE-binding bZIP factor, is an essential component of glucose signaling and its overexpression affects multiple stress tolerance. Plant J. 2004, 40, 75-87. [CrossRef] [PubMed] 
136. Yoshida, T.; Fujita, Y.; Sayama, H.; Kidokoro, S.; Maruyama, K.; Mizoi, J.; Shinozaki, K.; Yamaguchi-Shinozaki, K. AREB1, AREB2, and ABF3 are master transcription factors that cooperatively regulate ABRE-dependent ABA signaling involved in drought stress tolerance and require ABA for full activation. Plant J. 2010, 61, 672-685. [CrossRef] [PubMed]

137. Zhang, D.W.; Ye, H.X.; Guo, H.Q.; Johnson, A.; Zhang, M.S.; Lin, H.H.; Yin, Y.H. Transcription factor HAT1 is phosphorylated by BIN2 kinase and mediates brassinosteroid repressed gene expression in Arabidopsis. Plant J. 2014, 77, 59-70. [CrossRef] [PubMed]

138. Tan, W.R.; Zhang, D.W.; Zhou, H.P.; Zheng, T.; Yin, Y.H.; Lin, H.H. Transcription factor HAT1 is a substrate of SnRK2.3 kinase and negatively regulates ABA synthesis and signaling in Arabidopsis responding to drought. PLoS Genet. 2018, 14, e1007336. [CrossRef]

139. Danquah, A.; de Zelicourt, A.; Colcombet, J.; Hirt, H. The role of ABA and MAPK signaling pathways in plant abiotic stress responses. Biotechnol. Adv. 2014, 32, 40-52. [CrossRef]

140. Knetsch, M.L.W.; Wang, M.; SnaarJagalska, B.E.; HeimovaaraDijkstra, S. Abscisic acid induces mitogen-activated protein kinase activation in barley aleurone protoplasts. Plant Cell 1996, 8, 1061-1067. [CrossRef]

141. Brock, A.K.; Willmann, R.; Kolb, D.; Grefen, L.; Lajunen, H.M.; Bethke, G.; Lee, J.; Nurnberger, T.; Gust, A.A. The Arabidopsis Mitogen-Activated Protein Kinase Phosphatase PP2C5 Affects Seed Germination, Stomatal Aperture, and Abscisic Acid-Inducible Gene Expression. Plant Physiol. 2010, 153, 1098-1111. [CrossRef]

142. Xing, Y.; Jia, W.S.; Zhangl, J.H. AtMKK1 mediates ABA-induced CAT1 expression and H2O2 production via AtMPK6-coupled signaling in Arabidopsis. Plant J. 2008, 54, 440-451. [CrossRef] [PubMed]

143. Jammes, F.; Song, C.; Shin, D.J.; Munemasa, S.; Takeda, K.; Gu, D.; Cho, D.; Lee, S.; Giordo, R.; Sritubtim, S.; et al. MAP kinases MPK9 and MPK12 are preferentially expressed in guard cells and positively regulate ROS-mediated ABA signaling. Proc. Natl. Acad. Sci. USA 2009, 106, 20520-20525. [CrossRef] [PubMed]

144. Umezawa, T.; Sugiyama, N.; Takahashi, F.; Anderson, J.C.; Ishihama, Y.; Peck, S.C.; Shinozaki, K. Genetics and Phosphoproteomics Reveal a Protein Phosphorylation Network in the Abscisic Acid Signaling Pathway in Arabidopsis thaliana. Sci. Signal. 2013, 6, rs8. [CrossRef] [PubMed]

145. Ortiz-Masia, D.; Perez-Amador, M.A.; Carbonell, J.; Marcote, M.J. Diverse stress signals activate the C1 subgroup MAP kinases of Arabidopsis. Febs Lett. 2007, 581, 1834-1840. [CrossRef] [PubMed]

146. Danquah, A.; de Zelicourt, A.; Boudsocq, M.; Neubauer, J.; Frey, N.F.D.; Leonhardt, N.; Pateyron, S.; Gwinner, F.; Tamby, J.P.; Ortiz-Masia, D.; et al. Identification and characterization of an ABA-activated MAP kinase cascade in Arabidopsis thaliana. Plant J. 2015, 82, 232-244. [CrossRef]

147. Matsuoka, D.; Yasufuku, T.; Furuya, T.; Nanmori, T. An abscisic acid inducible Arabidopsis MAPKKK, MAPKKK18 regulates leaf senescence via its kinase activity. Plant Mol. Biol. 2015, 87, 565-575. [CrossRef]

148. Boudsocq, M.; Danquah, A.; de Zelicourt, A.; Hirt, H.; Colcombet, J. Plant MAPK cascades: Just rapid signaling modules? Plant Signal. Behav. 2015, 10, e1062197. [CrossRef]

149. Mauch-Mani, B.; Mauch, F. The role of abscisic acid in plant-pathogen interactions. Curr. Opin. Plant Biol. 2005, 8, 409-414. [CrossRef]

150. Ku, Y.S.; Sintaha, M.; Cheung, M.Y.; Lam, H.M. Plant Hormone Signaling Crosstalks between Biotic and Abiotic Stress Responses. Int. J. Mol. Sci. 2018, 19, 3206. [CrossRef]

151. Yang, J.; Duan, G.H.; Li, C.Q.; Liu, L.; Han, G.Y.; Zhang, Y.L.; Wang, C.M. The Crosstalks Between Jasmonic Acid and Other Plant Hormone Signaling Highlight the Involvement of Jasmonic Acid as a Core Component in Plant Response to Biotic and Abiotic Stresses. Front. Plant Sci. 2019, 10, 1349. [CrossRef]

152. Kusajima, M.; Yasuda, M.; Kawashima, A.; Nojiri, H.; Yamane, H.; Nakajima, M.; Akutsu, K.; Nakashita, H. Suppressive effect of abscisic acid on systemic acquired resistance in tobacco plants. J. Gen. Plant Pathol. 2010, 76, 161-167. [CrossRef]

153. Xia, X.J.; Wang, Y.J.; Zhou, Y.H.; Tao, Y.; Mao, W.H.; Shi, K.; Asami, T.; Chen, Z.X.; Yu, J.Q. Reactive Oxygen Species Are Involved in Brassinosteroid- Induced Stress Tolerance in Cucumber. Plant Physiol. 2009, 150, 801-814. [CrossRef] [PubMed]

154. Melotto, M.; Underwood, W.; Koczan, J.; Nomura, K.; He, S.Y. Plant stomata function in innate immunity against bacterial invasion. Cell 2006, 126, 969-980. [CrossRef] [PubMed]

155. Conrath, U.; Pieterse, C.M.J.; Mauch-Mani, B. Priming in plant-pathogen interactions. Trends Plant Sci. 2002, 7, 210-216. [CrossRef] 
156. Jakab, G.; Ton, J.; Flors, V.; Zimmerli, L.; Metraux, J.P.; Mauch-Mani, B. Enhancing Arabidopsis salt and drought stress tolerance by chemical priming for its abscisic acid responses. Plant Physiol. 2005, 139, 267-274. [CrossRef]

157. Yao, L.M.; Zhong, Y.P.; Wang, B.; Yan, J.H.; Wu, T.L. BABA application improves soybean resistance to aphid through activation of phenylpropanoid metabolism and callose deposition. Pest Manag. Sci. 2019, 76, 384-394. [CrossRef]

158. Tworkoski, T.; Wisniewski, M.; Artlip, T. Application of BABA and s-ABA for drought resistance in apple. J. Appl. Hortic. 2011, 13, 85-90.

159. Ton, J.; Jakab, G.; Toquin, V.; Flors, V.; Iavicoli, A.; Maeder, M.N.; Metraux, J.P.; Mauch-Mani, B. Dissecting the beta-aminobutyric acid-induced priming phenomenon in arabidopsis. Plant Cell 2005, 17, 987-999. [CrossRef]

160. Thevenet, D.; Pastor, V.; Baccelli, I.; Balmer, A.; Vallat, A.; Neier, R.; Glauser, G.; Mauch-Mani, B. The priming molecule beta-aminobutyric acid is naturally present in plants and is induced by stress. New Phytol. 2017, 213, 552-559. [CrossRef]

161. Chini, A.; Grant, J.J.; Seki, M.; Shinozaki, K.; Loake, G.J. Drought tolerance established by enhanced expression of the CC-NBS-LRR gene, ADR1, requires salicylic acid, EDS1 and ABI1. Plant J. 2004, 38, 810-822. [CrossRef]

162. Jagodzik, P.; Tajdel-Zielinska, M.; Ciesla, A.; Marczak, M.; Ludwikow, A. Mitogen-Activated Protein Kinase Cascades in Plant Hormone Signaling. Front. Plant Sci. 2018, 9, 1387. [CrossRef] [PubMed]

163. Kumar, M.; Choi, J.; An, G.; Kim, S.R. Ectopic Expression of OsSta2 Enhances Salt Stress Tolerance in Rice. Front. Plant Sci. 2017, 8, 316. [CrossRef] [PubMed]

164. Dubois, M.; Skirycz, A.; Claeys, H.; Maleux, K.; Dhondt, S.; De Bodt, S.; Vanden Bossche, R.; De Milde, L.; Yoshizumi, T.; Matsui, M.; et al. ETHYLENE RESPONSE FACTOR6 Acts as a Central Regulator of Leaf Growth under Water-Limiting Conditions in Arabidopsis. Plant Physiol. 2013, 162, 319-332. [CrossRef] [PubMed]

165. Seo, Y.J.; Park, J.B.; Cho, Y.J.; Jung, C.; Seo, H.S.; Park, S.K.; Nahm, B.H.; Song, J.T. Overexpression of the Ethylene-Responsive Factor Gene BrERF4 from Brassica rapa Increases Tolerance to Salt and Drought in Arabidopsis Plants. Mol. Cells 2010, 30, 271-277. [CrossRef] [PubMed]

166. Sewelam, N.; Kazan, K.; Thomas-Hall, S.R.; Kidd, B.N.; Manners, J.M.; Schenk, P.M. Ethylene Response Factor 6 Is a Regulator of Reactive Oxygen Species Signaling in Arabidopsis. PLoS ONE 2013, 8, e70289. [CrossRef]

167. Park, J.M.; Park, C.J.; Lee, S.B.; Ham, B.K.; Shin, R.; Paek, K.H. Overexpression of the tobacco Tsi1 gene encoding an EREBP/AP2-Type transcription factor enhances resistance against pathogen attack and osmotic stress in tobacco. Plant Cell 2001, 13, 1035-1046. [CrossRef]

168. Wang, H.; Huang, Z.J.; Chen, Q.; Zhang, Z.J.; Zhang, H.B.; Wu, Y.M.; Huang, D.F.; Huang, R.F. Ectopic overexpression of tomato JERF3 in tobacco activates downstream gene expression and enhances salt tolerance. Plant Mol. Biol. 2004, 55, 183-192. [CrossRef]

169. Zhang, G.Y.; Chen, M.; Li, L.C.; Xu, Z.S.; Chen, X.P.; Guo, J.M.; Ma, Y.Z. Overexpression of the soybean GmERF3 gene, an AP2/ERF type transcription factor for increased tolerances to salt, drought, and diseases in transgenic tobacco. J. Exp. Bot. 2009, 60, 3781-3796. [CrossRef]

170. Zhai, Y.; Wang, Y.; Li, Y.J.; Lei, T.T.; Yan, F.; Su, L.T.; Li, X.W.; Zhao, Y.; Sun, X.; Li, J.W.; et al. Isolation and molecular characterization of GmERF7, a soybean ethylene-response factor that increases salt stress tolerance in tobacco. Gene 2013, 513, 174-183. [CrossRef]

171. Finkelstein, R.R.; Gampala, S.S.L.; Rock, C.D. Abscisic acid signaling in seeds and seedlings. Plant Cell 2002, 14, S15-S45. [CrossRef]

172. Luerssen, K.; Kirik, V.; Herrmann, P.; Misera, S. FUSCA3 encodes a protein with a conserved VP1/ABI3-like B3 domain which is of functional importance for the regulation of seed maturation in Arabidopsis thaliana. Plant J. 1998, 15, 755-764. [CrossRef]

173. Stone, S.L.; Kwong, L.W.; Yee, K.M.; Pelletier, J.; Lepiniec, L.; Fischer, R.L.; Goldberg, R.B.; Harada, J.J. Leafy Cotyledon2 encodes a B3 domain transcription factor that induces embryo development. Proc. Natl. Acad. Sci. USA 2001, 98, 11806-11811. [CrossRef] [PubMed]

174. Brocard-Gifford, I.M.; Lynch, T.J.; Finkelstein, R.R. Regulatory networks in seeds integrating developmental, abscisic acid, sugar, and light signaling. Plant Physiol. 2003, 131, 78-92. [CrossRef] [PubMed] 
175. Bensmihen, S.; Rippa, S.; Lambert, G.; Jublot, D.; Pautot, V.; Granier, F.; Giraudat, J.; Parcy, F. The homologous ABI5 and EEL transcription factors function antagonistically to fine-tune gene expression during late embryogenesis. Plant Cell 2002, 14, 1391-1403. [CrossRef] [PubMed]

176. Bensmihen, S.; Giraudat, J.; Parcy, F. Characterization of three homologous basic leucine zipper transcription factors (bZIP) of the ABI5 family during Arabidopsis thaliana embryo maturation. J. Exp. Bot. 2005, 56, 597-603. [CrossRef] [PubMed]

177. Lopez-Molina, L.; Mongrand, S.; Chua, N.H. A postgermination developmental arrest checkpoint is mediated by abscisic acid and requires the AB15 transcription factor in Arabidopsis. Proc. Natl. Acad. Sci. USA 2001, 98, 4782-4787. [CrossRef]

178. Dekkers, B.J.W.; He, H.Z.; Hanson, J.; Willems, L.A.J.; Jamar, D.C.L.; Cueff, G.; Rajjou, L.; Hilhorst, H.W.M.; Bentsink, L. The Arabidopsis Delay of Germination 1 gene affects ABSCISIC ACID Insensitive 5 (ABI5) expression and genetically interacts with ABI3 during Arabidopsis seed development. Plant J. 2016, 85, 451-465. [CrossRef]

179. Kanai, M.; Nishimura, M.; Hayashi, M. A peroxisomal ABC transporter promotes seed germination by inducing pectin degradation under the control of ABI5. Plant J. 2010, 62, 936-947. [CrossRef]

180. Skubacz, A.; Daszkowska-Golec, A.; Szarejko, L. The Role and Regulation of ABI5 (ABA-Insensitive 5) in Plant Development, Abiotic Stress Responses and Phytohormone Crosstalk. Front. Plant Sci. 2016, 7, 1884. [CrossRef]

181. Seo, P.J.; Xiang, F.N.; Qiao, M.; Park, J.Y.; Lee, Y.N.; Kim, S.G.; Lee, Y.H.; Park, W.J.; Park, C.M. The MYB96 Transcription Factor Mediates Abscisic Acid Signaling during Drought Stress Response in Arabidopsis. Plant Physiol. 2009, 151, 275-289. [CrossRef]

182. Kim, J.H.; Hyun, W.Y.; Nguyen, H.N.; Jeong, C.Y.; Xiong, L.; Hong, S.W.; Lee, H. AtMyb7, a subgroup 4 R2R3 $\mathrm{Myb}$, negatively regulates ABA-induced inhibition of seed germination by blocking the expression of the bZIP transcription factor ABI5. Plant Cell Environ. 2015, 38, 559-571. [CrossRef] [PubMed]

183. Duan, L.N.; Dietrich, D.; Ng, C.H.; Chan, P.M.Y.; Bhalerao, R.; Bennett, M.J.; Dinneny, J.R. Endodermal ABA Signaling Promotes Lateral Root Quiescence during Salt Stress in Arabidopsis Seedlings. Plant Cell 2013, 25, 324-341. [CrossRef] [PubMed]

184. Achard, P.; Cheng, H.; De Grauwe, L.; Decat, J.; Schoutteten, H.; Moritz, T.; Van Der Straeten, D.; Peng, J.R.; Harberd, N.P. Integration of plant responses to environmentally activated phytohormonal signals. Science 2006, 311, 91-94. [CrossRef] [PubMed]

185. Casal, J.J.; Fankhauser, C.; Coupland, G.; Blazquez, M.A. Signalling for developmental plasticity. Trends Plant Sci. 2004, 9, 309-314. [CrossRef]

186. Piskurewicz, U.; Jikumaru, Y.; Kinoshita, N.; Nambara, E.; Kamiya, Y.; Lopez-Molina, L. The Gibberellic Acid Signaling Repressor RGL2 Inhibits Arabidopsis Seed Germination by Stimulating Abscisic Acid Synthesis and ABI5 Activity. Plant Cell 2008, 20, 2729-2745. [CrossRef]

187. Tang, W.J.; Ji, Q.; Huang, Y.P.; Jiang, Z.M.; Bao, M.Z.; Wang, H.Y.; Lin, R.C. Far-Red Elongated hypocotyl3 and far-red impaired response1 Transcription Factors Integrate Light and Abscisic Acid Signaling in Arabidopsis. Plant Physiol. 2013, 163, 857-866. [CrossRef]

188. Oh, E.; Kang, H.; Yamaguchi, S.; Park, J.; Lee, D.; Kamiya, Y.; Choi, G. Genome-Wide Analysis of Genes Targeted by Phytochrome Interacting Factor 3-LIKE5 during Seed Germination in Arabidopsis. Plant Cell 2009, 21, 403-419. [CrossRef]

189. Xu, D.Q.; Li, J.G.; Gangappa, S.N.; Hettiarachchi, C.; Lin, F.; Andersson, M.X.; Jiang, Y.; Deng, X.W.; Holm, M. Convergence of Light and ABA Signaling on the ABI5 Promoter. PLoS Genet. 2014, 10, e1004197. [CrossRef]

190. Rock, C.D. Pathways to abscisic acid-regulated gene expression. New Phytol. 2000, 148, 357-396. [CrossRef]

191. Martínez-Zapater, J.M.; Coupland, G.; Dean, C.; Koornneef, M. 16 The Transition to Flowering in Arabidopsis. Cold Spring Harb. Monogr. Arch. 1994, 27, 403-433.

192. Michaels, S.D.; Amasino, R.M. FLOWERING LOCUS C encodes a novel MADS domain protein that acts as a repressor of flowering. Plant Cell 1999, 11, 949-956. [CrossRef] [PubMed]

193. Chiang, G.C.K.; Barua, D.; Kramer, E.M.; Amasino, R.M.; Donohue, K. Major flowering time gene, FLOWERING LOCUS C, regulates seed germination in Arabidopsis thaliana. Proc. Natl. Acad. Sci. USA 2009, 106, 11661-11666. [CrossRef] [PubMed]

194. Choi, H.I.; Hong, J.H.; Ha, J.O.; Kang, J.Y.; Kim, S.Y. ABFs, A family of ABA-responsive element binding factors. J. Biol. Chem. 2000, 275, 1723-1730. [CrossRef] [PubMed] 
195. Jakoby, M.; Weisshaar, B.; Droge-Laser, W.; Vicente-Carbajosa, J.; Tiedemann, J.; Kroj, T.; Parcy, F.; Grp, B.R. BZIP transcription factors in Arabidopsis. Trends Plant Sci. 2002, 7, 106-111. [CrossRef]

196. Abe, M.; Kobayashi, Y.; Yamamoto, S.; Daimon, Y.; Yamaguchi, A.; Ikeda, Y.; Ichinoki, H.; Notaguchi, M.; Goto, K.; Araki, T. FD, a bZIP protein mediating signals from the floral pathway integrator FT at the shoot apex. Science 2005, 309, 1052-1056. [CrossRef]

197. Wang, Y.P.; Li, L.; Ye, T.T.; Lu, Y.M.; Chen, X.; Wu, Y. The inhibitory effect of ABA on floral transition is mediated by ABI5 in Arabidopsis. J. Exp. Bot. 2013, 64, 675-684. [CrossRef]

198. Xiong, F.; Ren, J.J.; Yu, Q.; Wang, Y.Y.; Lu, C.C.; Kong, L.J.; Otegui, M.S.; Wang, X.L. AtU2AF65b functions in abscisic acid mediated flowering via regulating the precursor messenger RNA splicing of ABI5 and FLC in Arabidopsis. New Phytol. 2019, 223, 277-292. [CrossRef]

199. Kang, J.; Hwang, J.U.; Lee, M.; Kim, Y.Y.; Assmann, S.M.; Martinoia, E.; Lee, Y. PDR-type ABC transporter mediates cellular uptake of the phytohormone abscisic acid. Proc. Natl. Acad. Sci. USA 2010, 107, 2355-2360. [CrossRef]

200. Kang, J.; Yim, S.; Choi, H.; Kim, A.; Lee, K.P.; Lopez-Molina, L.; Martinoia, E.; Lee, Y. Abscisic acid transporters cooperate to control seed germination. Nat. Commun. 2015, 6, 8113. [CrossRef]

201. Kuromori, T.; Miyaji, T.; Yabuuchi, H.; Shimizu, H.; Sugimoto, E.; Kamiya, A.; Moriyama, Y.; Shinozaki, K. ABC transporter AtABCG25 is involved in abscisic acid transport and responses. Proc. Natl. Acad. Sci. USA 2010, 107, 2361-2366. [CrossRef]

202. Kanno, Y.; Hanada, A.; Chiba, Y.; Ichikawa, T.; Nakazawa, M.; Matsui, M.; Koshiba, T.; Kamiya, Y.; Seo, M. Identification of an abscisic acid transporter by functional screening using the receptor complex as a sensor. Proc. Natl. Acad. Sci. USA 2012, 109, 9653-9658. [CrossRef] [PubMed]

203. Ge, K.; Liu, X.; Li, X.Y.; Hu, B.; Li, L. Isolation of an ABA Transporter-Like 1 Gene from Arachis hypogaea That Affects ABA Import and Reduces ABA Sensitivity in Arabidopsis. Front. Plant Sci. 2017, 8, 1150. [CrossRef] [PubMed]

204. Pawela, A.; Banasiak, J.; Biala, W.; Martinoia, E.; Jasinski, M. MtABCG20 is an ABA exporter influencing root morphology and seed germination of Medicago truncatula. Plant J. 2019, 98, 511-523. [CrossRef] [PubMed]

205. Kumar, M.; Kim, I.; Kim, Y.K.; Heo, J.B.; Suh, M.C.; Kim, H.U. Strigolactone Signaling Genes Showing Differential Expression Patterns in Arabidopsis max Mutants. Plants 2019, 8, 352. [CrossRef] [PubMed]

206. Lopez-Raez, J.A.; Kohlen, W.; Charnikhova, T.; Mulder, P.; Undas, A.K.; Sergeant, M.J.; Verstappen, F.; Bugg, T.D.H.; Thompson, A.J.; Ruyter-Spira, C.; et al. Does abscisic acid affect strigolactone biosynthesis? New Phytol. 2010, 187, 343-354. [CrossRef] [PubMed]

207. Huang, X.Z.; Hou, L.Y.; Meng, J.J.; You, H.W.; Li, Z.; Gong, Z.Z.; Yang, S.H.; Shi, Y.T. The Antagonistic Action of Abscisic Acid and Cytokinin Signaling Mediates Drought Stress Response in Arabidopsis. Mol. Plant 2018, 11, 970-982. [CrossRef]

208. Wang, L.; Waters, M.T.; Smith, S.M. Karrikin-KAI2 signalling provides Arabidopsis seeds with tolerance to abiotic stress and inhibits germination under conditions unfavourable to seedling establishment. New Phytol. 2018, 219, 605-618. [CrossRef]

209. Kumar, M.; Le, D.T.; Hwang, S.; Seo, P.J.; Kim, H.U. Role of the Indeterminate Domain Genes in Plants. Int. J. Mol. Sci. 2019, 20, 2286. [CrossRef]

210. Daviere, J.M.; Achard, P. A Pivotal Role of DELLAs in Regulating Multiple Hormone Signals. Mol. Plant 2016, 9, 10-20. [CrossRef]

(C) 2019 by the authors. Licensee MDPI, Basel, Switzerland. This article is an open access article distributed under the terms and conditions of the Creative Commons Attribution (CC BY) license (http://creativecommons.org/licenses/by/4.0/). 